\title{
AN ANALYSIS FOR INDUSTRIAL DEVELOPMENT IN TURKEY. I: DISTRIBUTION OF THE LARGEST COMPANIES
}

\author{
Ahmet Yucekaya* \\ Industrial Engineering Department, Kadir Has University, Istanbul, Turkey \\ ahmety@khas.edu.tr
}

\begin{abstract}
The location of large companies can be used to analyze the distribution of industrial facilities and capital. Turkey, an emerging economy, has experienced a rapid change for the last two decades in terms of industrial change. In this paper, we propose a trend analysis-based methodology to analyze the development of the largest 500 companies in Turkey in an effort to observe the regional change and development. We first analyze the number of companies in seven regions between 2012 and 2015 and observe that the number of the largest companies move from the developed regions to less developed regions. A city-based research on the most important cities for the analysis is also included in our project. It is observed that central industrial cities including Istanbul rapidly lose their largest companies to other cities. The results of the city and region analysis confirm that a higher number of large companies are likely to emerge in different cities and regions of the country.
\end{abstract}

Keywords: The largest companies, trend analysis, regional analysis, urban analysis, location of companies

\section{Introduction}

Developments in the infrastructure of technology and the communication have changed the structure of the business world: its processes and habits. There has been a rapid change in especially the last twenty years. The internet and technology has led new companies to grow and some industries to collapse. The economic crises, company acquisitions and development of new industries are also more common than ever. This change has also resulted in local companies to grow and compete with larger companies without moving to industrial centers. The increasing transportation options and decreasing cost of logistics are among other factors rendering this regional growth possible. 
Emerging economies experienced rapid changes in company sizes, business models and innovation. Globalization, population growth and technological developments make these changes faster and wider. The change in the number of the largest companies operating in different sectors and regions is a good indicator of this industrial change. As the technology, communication infrastructure and customer preferences change, the company sizes in different regions are also expected to change. Technology oriented companies have suddenly become the largest companies and they've had more revenue than large companies with traditional business expertise. Innovation and competition also play an important role in this process. Communication and transportation infrastructure led local companies to grow and have competition potential.

Turkey, an emerging economy, has observed a rapid change in the last decade and gained economic acceleration along with growth and development. The European Union (EU) membership application process, which officially began in 1999 after Turkey's candidate status was approved by the European Council, forced the country to make the regulations. The Brexit process which include Great Britain to exit from the EU continues and that might affect the relationship with Turkey. The industry and companies in general benefited from this positive acceleration. To be a part of the EU, the country had significant obligations in aspects not only economic, but also social, cultural, political and judicial. The economic crises in 2001 had severely affected the economy and banking sector and forced new regulations to come into play. The period beginning with the year 2002 has completely different characteristics than any other time in terms of economic development. The industry and the companies have observed a growth as the country started official negotiations in 2004. Turkey is located in a strategically significant area, in Anatolian Peninsula, where the continents of Asia, Europe and Africa are at the closest to each other. It acts as a bridge connecting the east and the west and its geopolitical position affects its economy, industrial change, politics and internal and external strategies. In the aftermath of three crucial coup d'etats (on 27th May 1960, 12th March 1971, and 12th September 1980), not only the political situation but also the economy of the country had been affected. Economic liberalization and new policies to open the country to international markets after 1980 enabled the country to overcome the destructive effects of the coup d'états and the commercial, economic, political, and legal recession they had caused. The high inflation rates between 1984 and 2001 and in 2008 were considered as an important problem for the instability [1]. The decrease in the Gross Domestic Product (GDP) in years 1991, 1994, 1997, 1999, 2001 and between 2008 and 2009 compared to the previous years affected the growth rates. High unemployment and interest rates are the other factors which affected the industry [2]. Sacik (2009) notes that the industrialization model adopted in Turkey from the 1960s onwards was 'import substitution industrialization' [3]. The model proposes that the country should produce the goods it used to import from other countries. The goods produced internally in this model were mainly consumer durable goods such as refrigerators, televisions, radios, vacuum cleaners, ovens, and washing machines. Egeli (2001) states that the import substitution industrialization model also aimed to prevent the Turkish economy from being negatively influenced by the more powerful and dominant external and/or international economies [4]. The government imposed strict regulations to implement the model. The level of customs duties on imported goods were increased and quotas were set in order to restrict the importation and, even prohibitions on some of the most imported goods were enforced. From the 1980s onwards the government started to follow an export-oriented growth model. In this type of industrialization strategy, countries put emphasis not on all industrial goods but on the ones the country has a competitive advantage with. Authors claim that the main objective is to focus on exportation of goods produced within the borders of the country and therefore increase the income and 
welfare levels, as well as enhancing the development of the country's economy [5]. The increasing exportation makes a contribution to the total factor productivity and hence another reason for the government to adopt the model of industrialization and economic growth.

The earthquake of the 17thAugust 1999 severely affected the most efficient and significant industrial zones in the country including those in the cities of Istanbul, lzmit, Sakarya, and Yalova. 23\% of the entire population used to live in the cities which had been affected by the natural disaster. The percentage of the seven cities that have been affected by the earthquake in gross national product was 34.7\%. The cities of lzmit, Sakarya, and Yalova that have been affected at the top level had the $6.3 \%$ of the gross national product. The region had a significant importance in the production of motor vehicle, petroleum chemicals, petroleum refining, textile raw material and main metal industries.

The earthquake has caused a lot of damages and losses in addition to the death of the region's many residents. A great number of blocks of houses, commercial and/or industrial buildings, roads and highways, bridges, all other sorts of infrastructure; public transport vehicles, machines and equipment, and the stocks of ready and semi-ready goods have been seriously damaged and/or have become non-functional. The earthquake, therefore has caused serious and long-term damages in the economy of the country.

The global economic crisis of 2007 spread to the other countries. It has inevitably had negative effects on the economic system and structure as well as the economic growth process in Turkey. Within this context, not only the macroeconomic factors but also their interactions with each other and with the socio- economic, legal, social, and political parameters have a significant impact on the economic performance and industrial development of Turkey. During the period of 2002-2015, national income nearly tripled, per capita income more than doubled and annual average growth rate reached to levels that made Turkey at the top of the list among developing countries [2]. The inflation was reduced to one-digit levels after a 30year period of chronically high inflation rates, public debt burden and budget deficit were reduced to minimum values. However, not all the regions and cities might benefit from such development. The region-based distribution of wealth and, industrial facilities throughout the country is desired and often supported by the government. New facilities attract investment, create new jobs and support the suppliers. As the economic development changes the structure of the industry some companies grow and some lose power. The outcomes of these changes on regional and sectoral development as well as the number of the largest companies is a subject worthy of research.

In literature, there are some researches about regional development. Researchers use three major centers and three minor centers of venture capital to observe the investments and their effect on regional development [6]. They point out that the venture capital investments significantly accelerate the pace of development in the regions. Authors analyze the development in southeast European countries using a multivariate statistical method for ranking entities to rank countries [7]. Armstrong and Read(2002) present a research for economic growth and vulnerability of small states and territories [8]. They use sectoral variables such as tourism, agriculture, finance and manufacturing along with other parameters to track the economic growth and vulnerability. The usage of sectoral information for regional development is also used in [9]. Focusing on the location decisions of companies they find out that assistance for regional development, labor supply and potential future expansion are the most important factors. They also emphasize that the influence levels of factors change considerably in different industrial sectors. There are also researches about measuring the 
regional development of a particular area. The indicators can be classified as the economic indicator, social indicator and environmental indicators. Economic indicators include variables such as GDP/GNP/GNI per capita, unemployment rate, income and, home ownership. Social indicators include variables such as birth rates, life expectancy, education and, infant mortality; while environmental indicators consist of variables such as forest cover, pollution level and, protected areas. Industrial growth brings new employment, investment and welfare which are classified as economic indicators.

Turkcan et al.(2009) use clusters for industries to analyze the regional development in Turkey. They also present the analysis for Japan, Israel, Scotland and Italy to show the importance of clusters in regional economy [10]. Onis and Senses(2009) provides an extensive analysis for the integration of Turkish economy and industry to global economy. They analyze how Turkish small and medium enterprises took a role in transforming of Turkish economy [11]. Another analysis for the economic change in Turkey is presented in Senses (2011) [12]. The research on the company characteristics and growth performance are limited but they present useful hints for the industrial growth Erserim(2012) [13].

Rezende and Sinay (2016) use economic and social indicators to analyze regional development [14]. They use GDP per capita, per capita budget revenues, median income of household, infant mortality and average education duration as indicators. Horsley et al.(2015) has researched regional development in mining economies [15]. Harrington et al.(1986) analyses foreign investment and regional development [16]. They focus on the Canadian companies in western New York and show the effect of investments on regional development. Lipshitz(1993) presents the main approaches for measuring regional development [17]. He points out that inter-regional inequality in terms of development, welfare level and economic growth rates exist in almost every country. Research also shows that the location of the largest companies might affect the regional development and vice versa [18], [19], [20], [21], [22], [23], [24].

There are also some researches on geographical analysis of industrial facilities in which the effect of policies on the development are analyzed. Kaygalak and Reid (2016) presents a research for the change in large enterprises in Turkey. The data include locations, employee numbers, and manufacturing characteristics of the companies and they use clustering to track the changes [25]. The geographic concentrations of the industries, companies and sectors are analyzed in different sources [26], [27], [28], [29], [30]. They show that the distribution of the largest companies does change based on the industrial and economic development.

In this paper, we analyze the historical data for the 500 largest companies in Turkey through a fourteen-year period in an effort to draw a picture of the industrial development in the country. We focus on the industrial development and track the share of the largest companies in each region to analyze the regional development. It is true that regional development is a multi-dimensional phenomenon and it should be discussed based on all indicators [31], [32], [33], [34]. However, for the time being we present only this part of the analysis and leave the other indicators for future research.

The annual data prepared for the companies based on their sales revenue are analyzed using statistical and data analysis methods and the results are presented. The data is huge and includes many variables for the companies, industries, regions and ownerships. In this research, we develop a method to analyze the change in regional distribution of the largest companies over the years in an effort to show the industrial development in region and in 
main cities. The list of largest companies of Turkey show major enterprises that have a certain market share and it is expected that they have economic benefit to the cities and regions. A trend analysis is also included to show the long term trend in each region. It is obvious that such analysis will depend on the structure of the regions and the country. The analyses will be made for seven main regions of Turkey and a similar work will be presented for the selected cities. Section 2 includes the method and characteristics of the data. In Section 3 the regional distribution is discussed while in section 4 city-based distribution of the largest companies is examined. Section 5 and 6 focus on the discussion and conclusion, respectively.

\section{The method and the data}

The structure of industry and the companies operating in each sector are good indicators of an economy and industrial change. Istanbul Chamber of Commerce (ISO) prepares a report to classify the largest 500 companies of the country each year since 1968. The economic activities in sectors are coded according to UN ISIC Rev.2 [35]. The report reflects the trends and the current state of the country's economy and industry. The analyzed companies are selected from industrial sectors. The companies are ordered according to their product salesbased revenue and the first 500 companies are announced. The majority of the first 500 companies are from the petrochemicals, automotive, and steel and iron industries.

The report also includes parameters such as total sales, gross added value, equity, net asset, period income and outcome before tax, exports, and number of employee of the companies. Our main objective in this paper is to analyze the level of industrial change in the country through the regional distribution of the country. We have reviewed the reports for top 500 companies for the 2002-2015 period in an effort to analyze the industrial change. The coup attempt in July, 2016 affected the natural business process in Turkey. However, we have not been able to wait for the list of 2016 to be announced. We believe that the list of 2016 might mislead the results as there is still an emergency decree in the country. Below is the notation used in the analysis in Table 1.

Table 1. Notations used for the analysis

\begin{tabular}{|c|c|c|}
\hline i & : & Region index \\
\hline $\mathrm{t}$ & $:$ & Year index \\
\hline $\mathrm{j}$ & $:$ & Company index (each company assigned a unique code) \\
\hline $\mathrm{k}$ & $:$ & City index \\
\hline $\mathrm{I}$ & $:$ & Total number of regions \\
\hline $\mathrm{J}$ & $:$ & Total number of companies \\
\hline $\mathrm{K}$ & $:$ & Total number of selected cities \\
\hline $\mathrm{Cj}, \mathrm{i}, \mathrm{t}$ & $:$ & $\begin{array}{l}1 \text { Company } \mathrm{j} \text { belongs to region } \mathrm{i} \text { and is in the largest companies list in year } \mathrm{t} \\
0 \text { Otherwise }\end{array}$ \\
\hline $\mathrm{Sj}, \mathrm{k}, \mathrm{t}$ & : & $\begin{array}{l}1 \text { Company } \mathrm{j} \text { belongs to city } \mathrm{k} \text { and is in the largest companies list in year } \mathrm{t} \\
0 \text { Otherwise }\end{array}$ \\
\hline $\mathrm{Mi}, \mathrm{t}$ & $:$ & Total number of companies in region $\mathrm{i}$ in year $\mathrm{t}$ \\
\hline $\mathrm{Lk}, \mathrm{t}$ & : & Total number of companies in city $\mathrm{k}$ in year $\mathrm{t}$ \\
\hline $\mathrm{Pi}, \mathrm{t}$ & $:$ & Percentage of region $\mathrm{i}$ in year $\mathrm{t}$ \\
\hline $\mathrm{Bk}, \mathrm{t}$ & $:$ & Percentage of city $\mathrm{k}$ in year $\mathrm{t}$ \\
\hline $\mathrm{R}$ & : & Trend analysis value or slope \\
\hline
\end{tabular}

In order to track the number of companies in each region and selected cities, we first assign a unique code to each company. It is possible for some companies to change their region, their 
name or go out of the list for some years and return later. We track the performance of each company through the years and calculate Mi,t and Lk,t as below:

$$
\begin{aligned}
& M_{i, t}=\sum_{j=1}^{J} \sum_{i=1}^{I} \sum_{t=2002}^{T} C_{j, i, t} \\
& L_{k, t}=\sum_{j=1}^{J} \sum_{k=1}^{K} \sum_{t=2002}^{T} C_{j, k, t}
\end{aligned}
$$

It is now possible to compute ratio of each region and city for each year using Eq. (3) and (4), respectively.

$$
\begin{aligned}
P_{i, t} & =\frac{M_{i, t}}{J} \\
B_{k, t} & =\frac{L_{k, t}}{J}
\end{aligned}
$$

The algorithm first finds $\mathrm{Cj}, \mathrm{i}, \mathrm{t}$ and $\mathrm{Cj}, \mathrm{k}, \mathrm{t}$ then computes total number of companies in each region and the selected cities for each year. Then, it is possible to compute Pi,t, Bk,t, R values for the analysis period. The pseudo-code for the analysis is given in Figure 1 below.

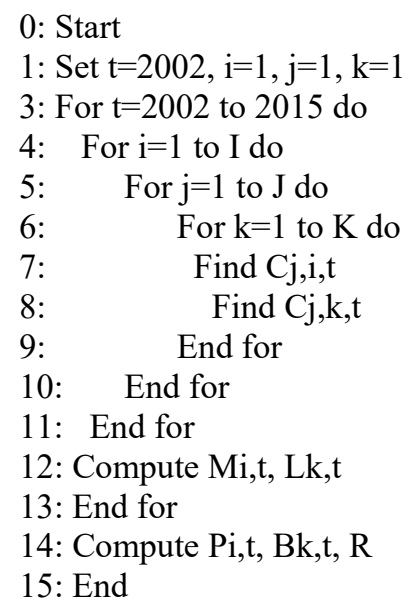

Figure 1. Pseudo code for regional analysis

We first present the general indicators of the Turkish economy for the period of 2002-2015 to reflect a better picture. The data were gathered from the Turkish Statistical Institute and verified by the Ministry of Economic Affairs, OECD and IMF reports. In the next section, we analyze the top 500 industrial companies based on the general indicators, exports and net sales.

\subsection{The general indicators}

As a result of the two earthquakes and the decreasing economic activity, the GDP in Turkey decreased by $3.4 \%$ in 1999 . The country had $-6.8 \%$ and $-5.7 \%$ GDP growth in 2000 and 2001, respectively due to the economic crises. The global financial crisis also affected the economy in Turkey within these years. The country has had a continuous growth after 2009 while the average GDP growth was observed as $4.6 \%$ between 1999 and 2015.

GDP per capita has also shown a similar structure with an increasing trend in the 2002-2008 period. Figure 2 provides the GDP per capita for the period of 2002 and 2015. There is a 
small decrease in 2008 because of the global financial crisis but the trend turns to up again in 2009. GDP per capita is $\$ 10.979$ in 2015.

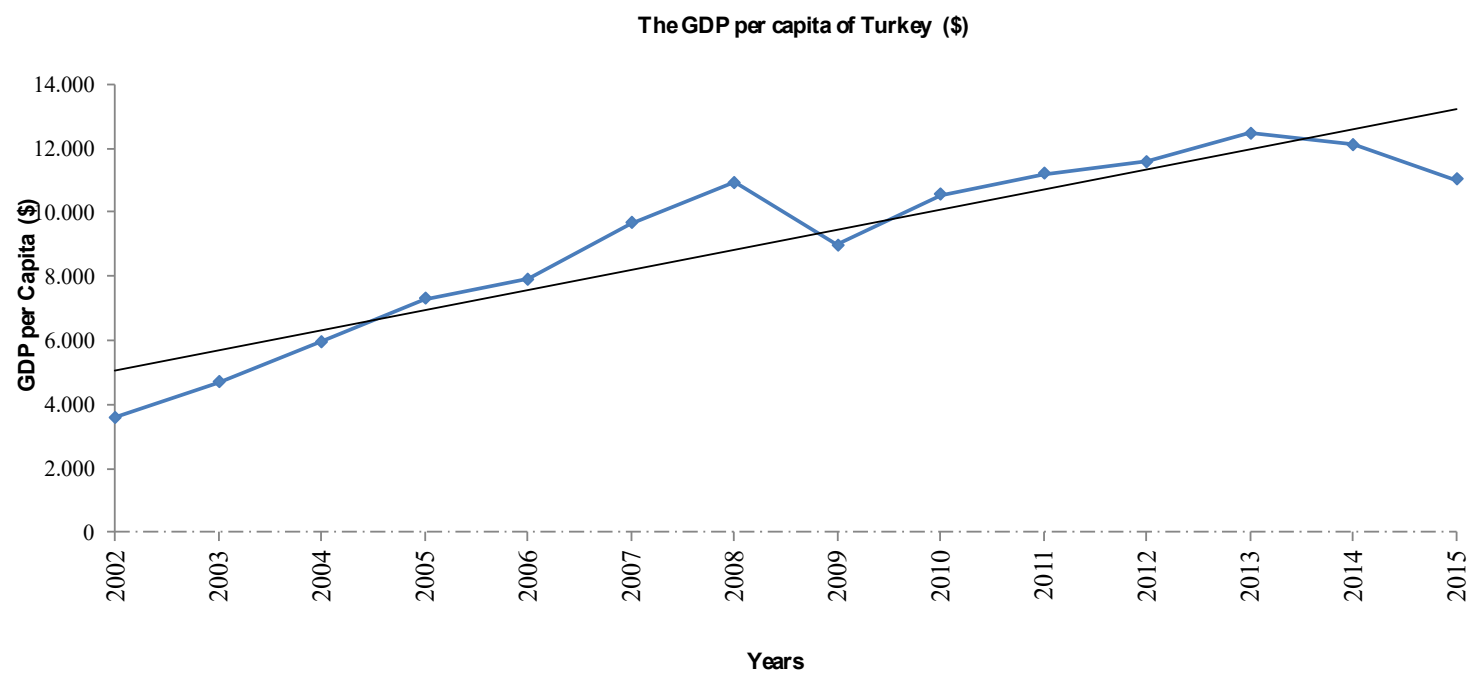

Figure 2. Turkey's GDP per Capita between 2002 and 2015

The emerging economies try to be an export dominant economy so as to attract foreign investment and balance their deficit. Figure 3 shows the total export between 2002 and 2015 . Starting at $\$ 31,334,216,000$ in 2002, it had a steady increasing trend from 2002 to 2008. Like the other indicators, exports were affected from the global crisis in 2008 and the rate decreased by $22.68 \%$. The increasing trend resumes in 2009 and reached $\$ 152,461,736,556$ in 2015 .

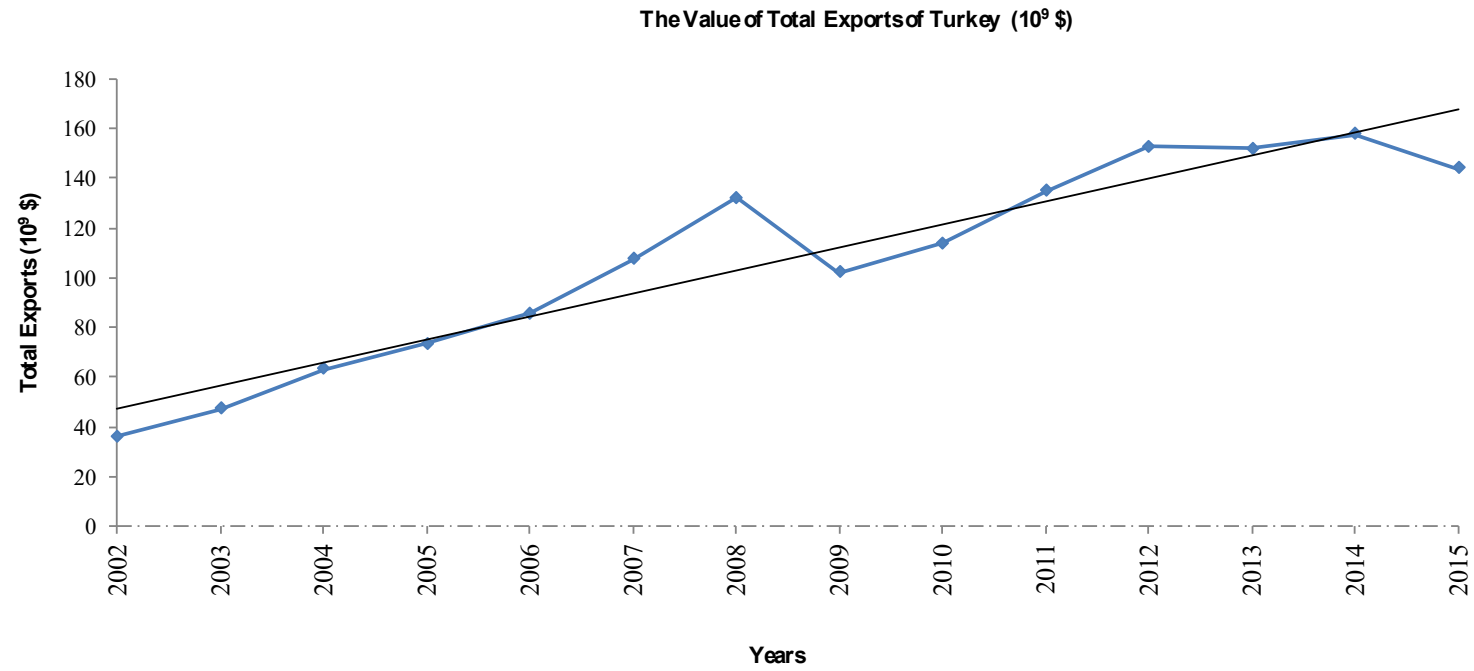

Figure 3. Turkey's Total Export between 2002and 2015

The production-based sales for the largest 500 companies shows a picture of the industrial activity in the country. Figure 4 demonstrates the total production-based sales of the largest 500 companies in 2002-2015. As expected, the growth has a similar pattern with the growth of the GDP and total exports. There is an increasing trend in 2002-2008 and a volatile trend was observed in 2008 because of the economic crisis. The value of the Turkish Lira also effects the value of the sales. Even if the value increases in terms of Lira, the value in terms of 
dollar decreases. The Lira has lost 13\% and 25\% value in 2014 and 2015, respectively, decreasing the value of the production-based sales for these years.

Production-based Sales $\left(10^{9} \mathrm{~S}\right)$

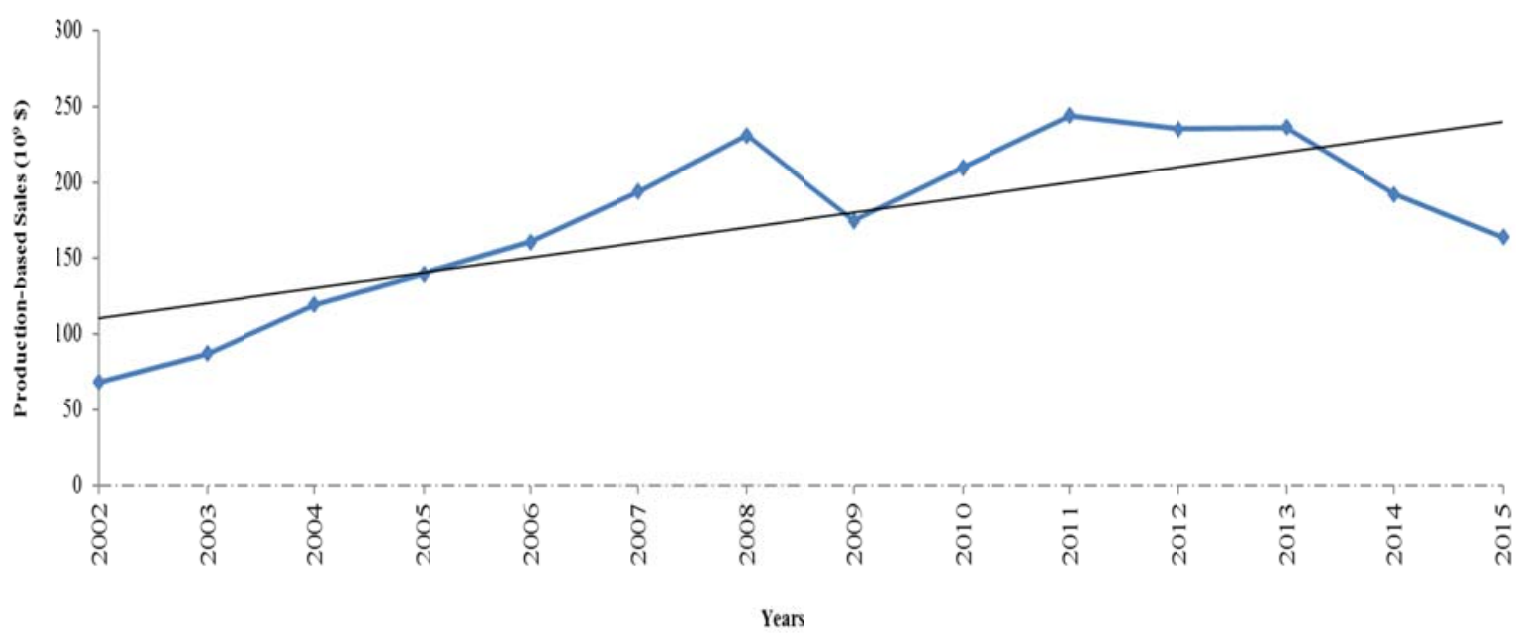

Figure 4. Production based sales for 500 largest companies in 2012-2015

The total export of the largest 500 companies was $\$ 17,375,819,000$ in 2002 . The total growth was realized as $389.71 \%$ in $2002-2008$ and export reached to $\$ 67,715,905,000$. In 2008 , export decreased by $31.73 \%$ because of the turmoil. However, in 2009 the trend started to increase again. In 2015, the total export figure of the largest 500 companies of Turkey was $\$ 63,712,230,000$. Figure 5 depicts the change in total export of the 500 largest companies.

The Value of Exports (10's)

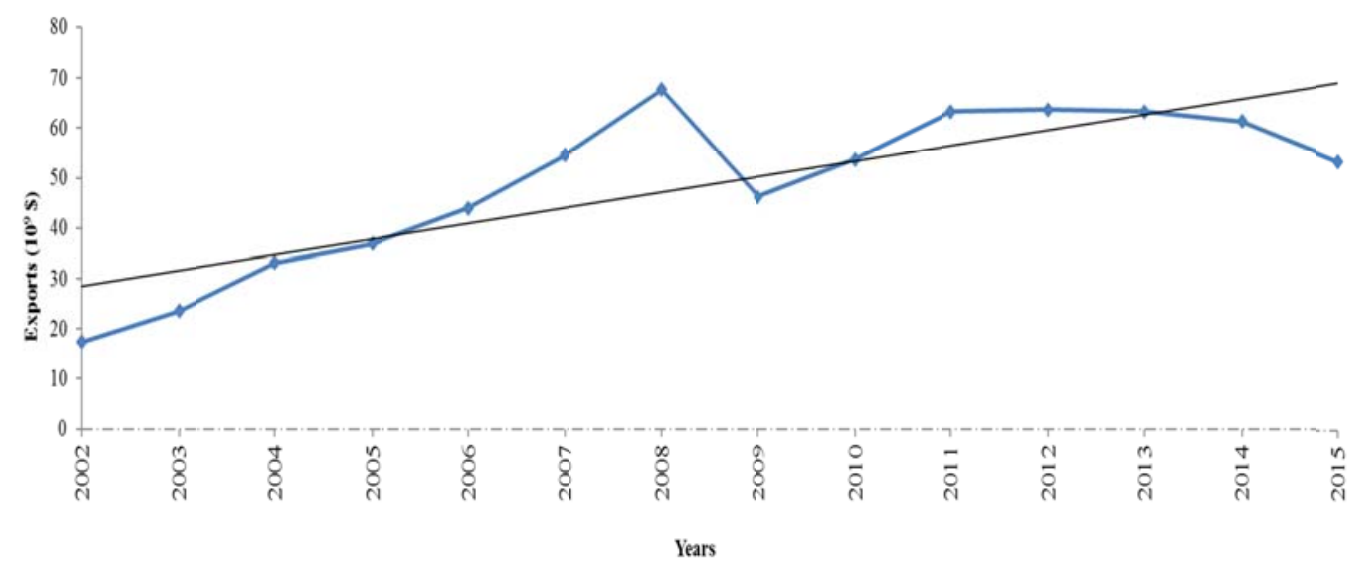

Figure 5. Total export of the 500 largest companies in 2012-2015

\section{The distribution of the largest companies}

We classify the companies based on the geographic regions and cities in an effort to observe the change in the regional distribution of the companies and industrial change. We compute $\mathrm{Mi}, \mathrm{t}$ and $\mathrm{Pi}, \mathrm{t}$ values for the regions and $\mathrm{Lk}, \mathrm{t}$ and $\mathrm{Bk}, \mathrm{t}$ values for the selected cities. The results are presented in the figures. 


\subsection{The regional distribution}

Turkey has seven geographic regions classified on their natural and economic characteristics. The Aegean, Black Sea, Central Anatolia, Eastern Anatolia, Marmara, Mediterranean, and South Eastern Anatolia regions have different importance for industrial production. Figure 6 presents a general overview of Turkey's regions [2]. Each region has different characteristics and potential such as transportation opportunities, workforce, political preferences and terrorism activities.

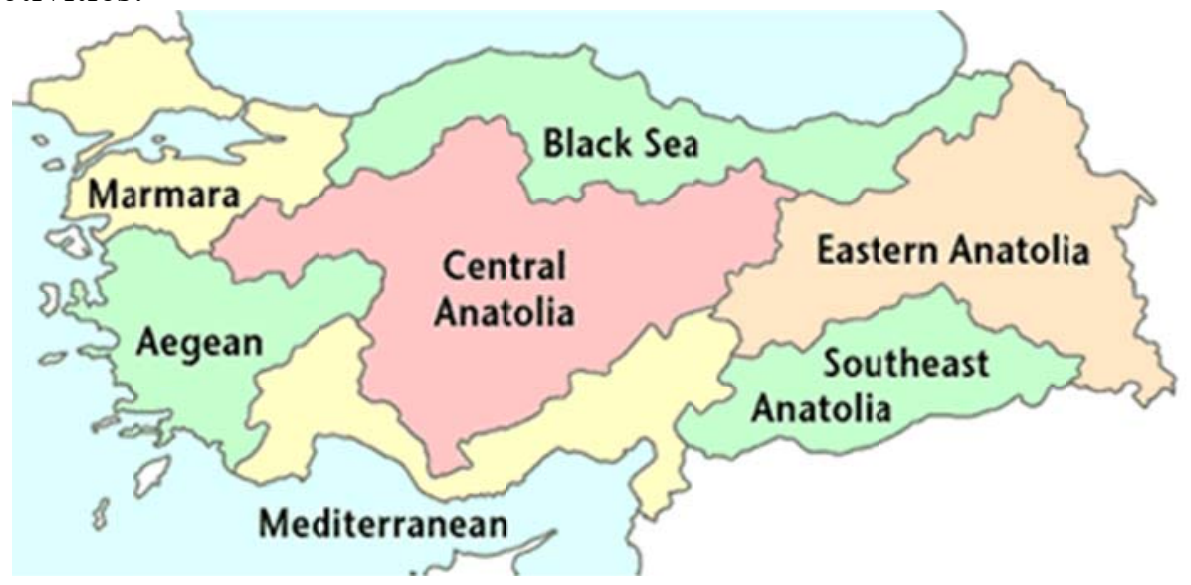

Figure 6. Regions of Turkey

The distribution of the largest industrial companies throughout the country affects employment and regional development, therefore has great significance. Eastern Anatolia and Southeast Anatolia are considered as less developed regions. The change in the number of the largest companies in each region also reflect the change in the business and culture of the region.

The Mediterranean region is in the south of Turkey near the Mediterranean Sea and has marine transportation opportunities. The region has a well-developed Tourism sector attracting visitors from all around the world. The region is also well known for agricultural products such as wheat and cotton. The majority of the companies in the list produce food, food derivative and textile. Products requiring high technology are not produced in the area and it can be claimed that companies in the region enjoys the advantages of the land. The region has access to ports and transportation to other parts of the country. The exportation of the produced goods is also possible through the ports. Figure 7 presents the total number of companies and respective percentages in the region. In 2002, the Mediterranean region had a $5.8 \%$ share in the list with 29 companies. Region had a relatively stable position in 2002-2009 but the number of companies rose to 30 in 2009 and its share increased by $6 \%$. The increasing trend continued until 2015 and the share rose by $9 \%$ with 45 companies. 


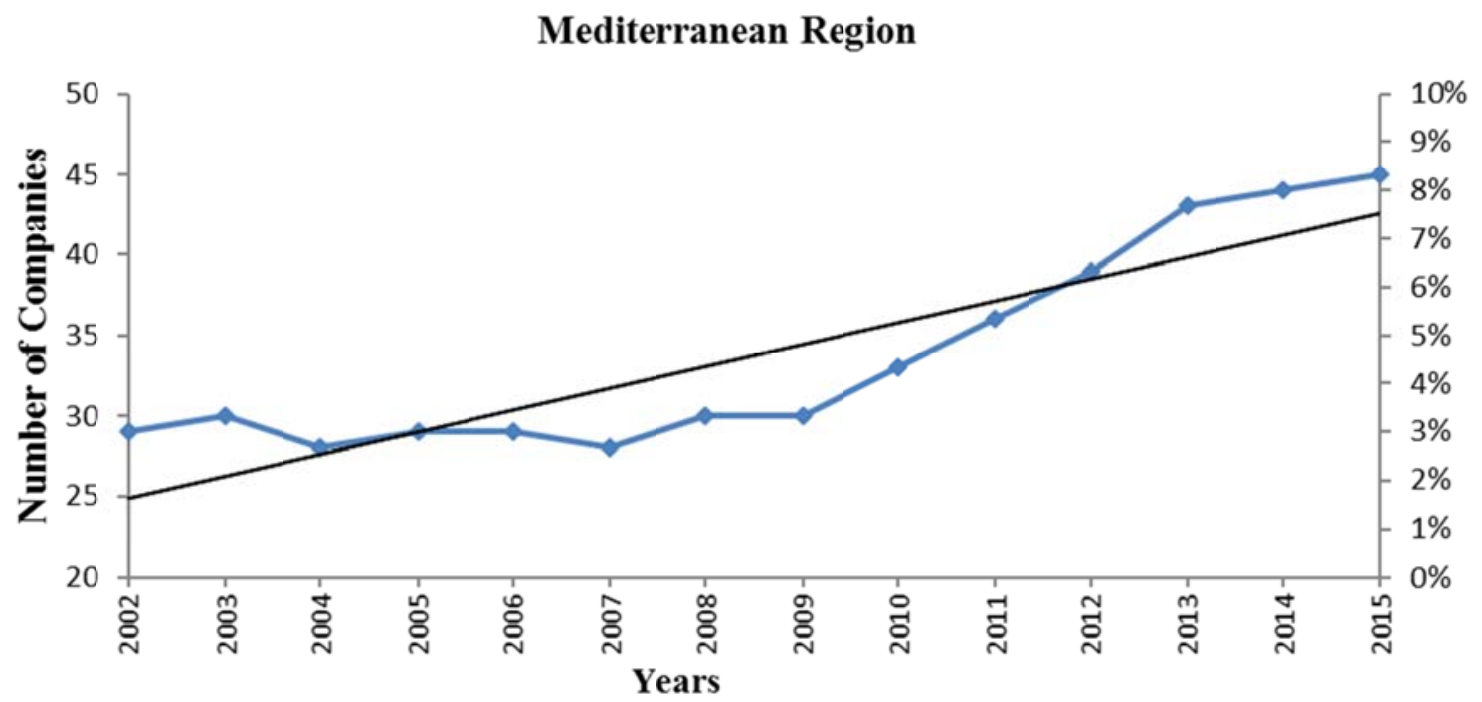

Figure 7. The number of companies in the Mediterranean Region in 2012-2015

The Marmara region which includes Istanbul has always been the business center and the heart of the industrial production in Turkey. Marmara is located in the northwest of Turkey near the Marmara, Black and Aegean Seas. It is the most crowded region of the country. The location is considered as a hub and the major transportation center to international and national destinations. The region has direct links to highways connecting Asia and Europe and direct borders with Greece and Bulgaria. The cities of Istanbul, Kocaeli and Bursa located in the region are considered as the center for industrial production and transportation hubs. The heavy industry, automotive industry, spare parts suppliers, energy companies and food derivative industries have production facilities in the region. Figure 8 presents the total number of companies in the region. In 2002, this region had 58.2\% share with 291 companies in the list of the top 500 companies. The region had an increasing trend in 2002-2007 and the number of companies rose up to 308 in 2007 and its share increased by $61.6 \%$. The increasing trend reversed in 2008 and the share decreased by $57.8 \%$ with 289 companies. This decreasing trend continued until 2015 and the region had 52.8\% share with 264 companies. The region obviously loses the largest companies to other regions. 


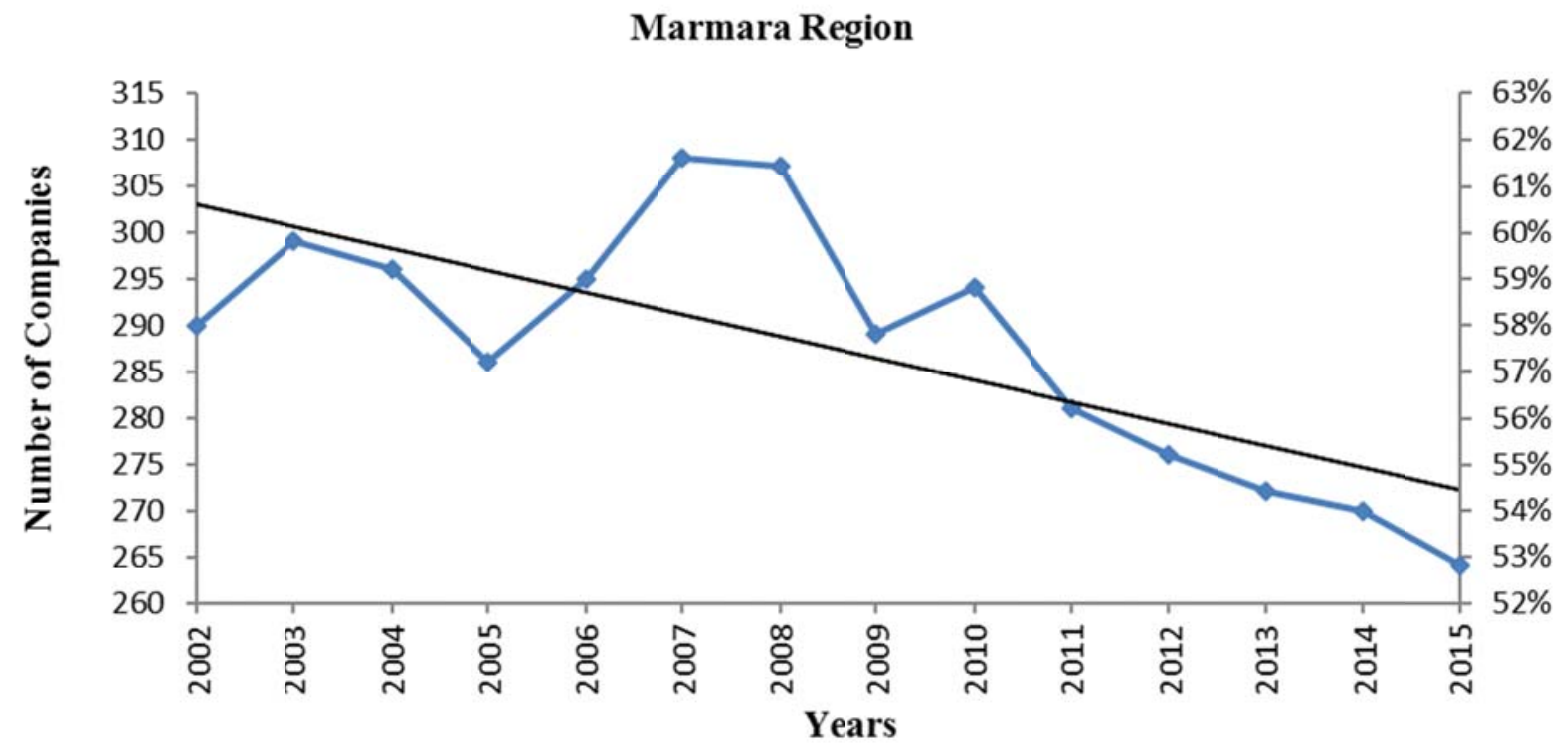

Figure 8. The number of companies in the Marmara Region in 2012-2015

The Aegean region is on the west side of Turkey on the coast of the Aegean Sea and has direct access to ports and highways. The region is similar to the Marmara region in terms of structure and industry composition. The main companies in the list include spare parts producers, chemical derivatives and food derivatives. Mining is another important business activity in the region. Figure 9 presents the total number of companies in the region between 2002 and 2015. According to the analysis, in 2002, the region had a 13.6\% share with 68 companies in the list. The figure had a sharp decline in 2007 and the number of companies went down to 56 in 2007 with a share of $11.2 \%$. The number of companies increased again after 2011 reaching to 66 in 2015. In general, the region had a decreasing trend in terms of the number of companies.

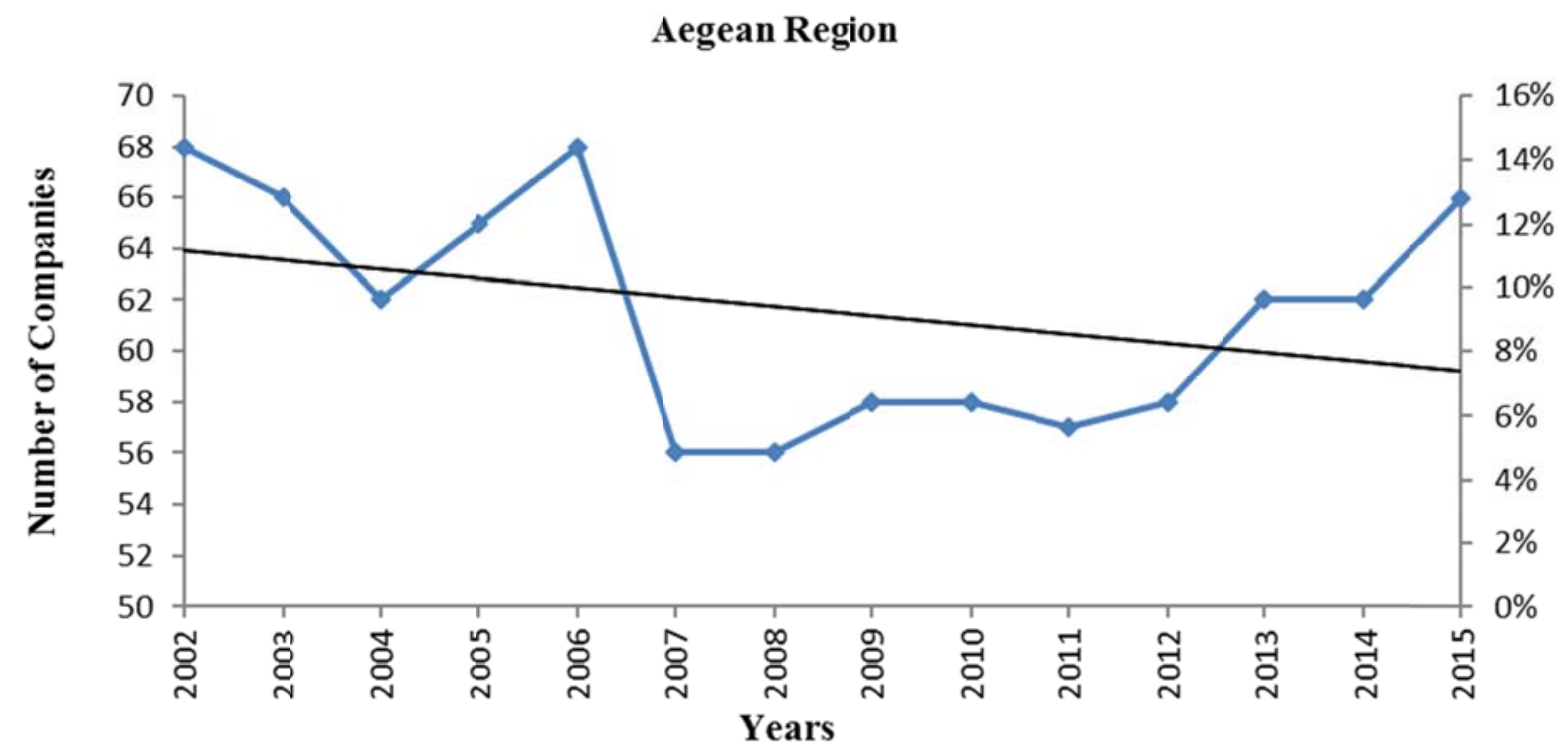

Figure 9. The number of companies in the Aegean Region in 2012-2015 
The Black Sea region is located in the north of Turkey on the Black Sea coast. The region has access to ports and major highways with developed transportation opportunities. Here agricultural products and food derivatives are processed and distributed to national and international destinations. The region is considered a world leader in hazelnut production and an important player in Turkish tea production. There are also cement and spare parts producing companies in the region which borders with the Marmara region. Figure 10 provides the total number of companies and respective percentage in total. The region had 17 companies in 2002 with $3.4 \%$ share. While its trend was in increase between 2002 and 2005, it decreased between 2005 and 2009. The number of companies within this period reached 29 in 2011 with a share of $5.80 \%$. The number of companies has shown a volatile trend reaching 25 in 2015 corresponding to a share of 5\%. In general, the region had an increasing trend in terms of number of companies in 2002-2015.

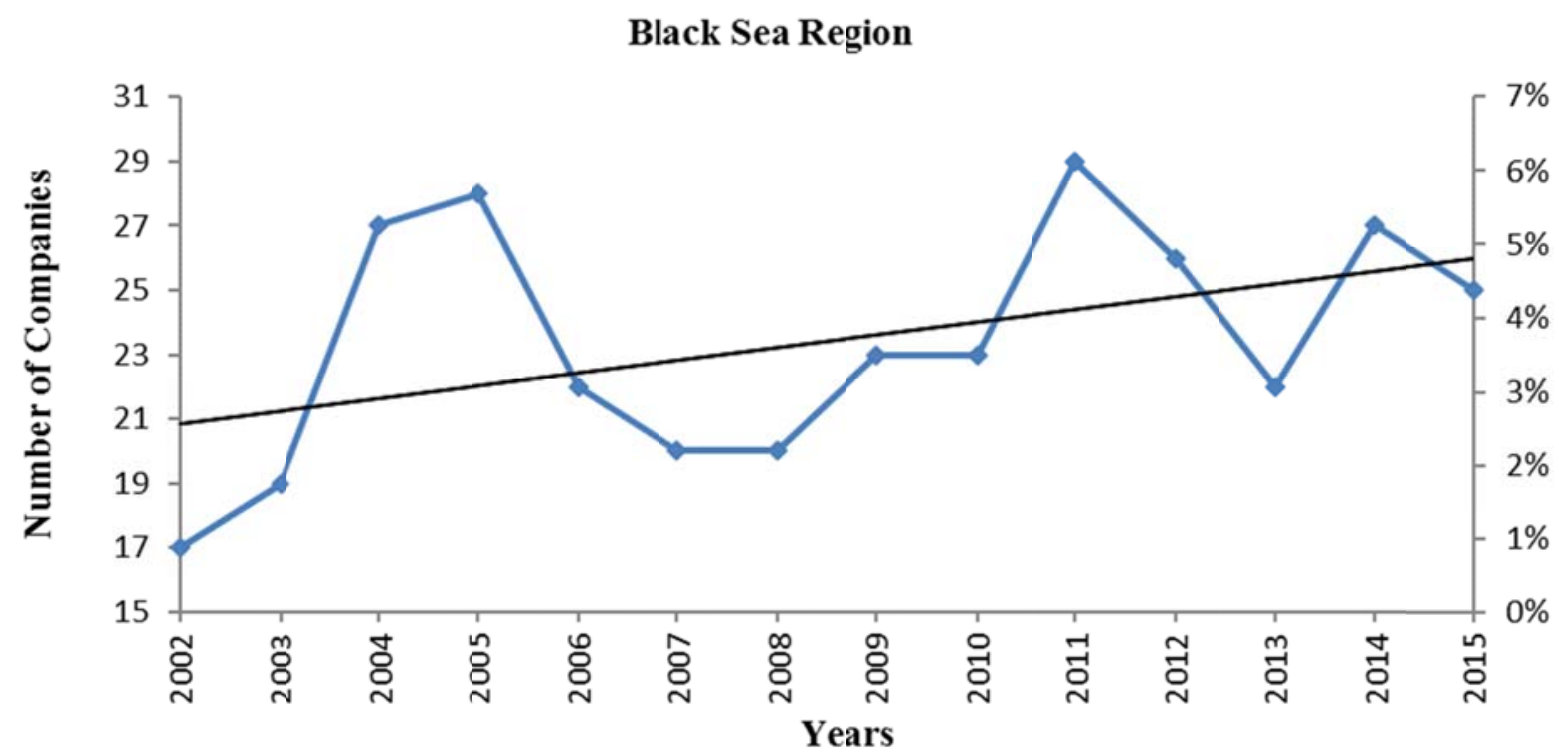

Figure 10. The number of companies in the Black Sea Region in 2012-2015

The Central Anatolia Region located in the center of Turkey has transportation opportunities except marine transportation. Ankara, the capital city of Turkey is located in the region. Kayseri, Konya, Eskisehir and Kirikkale are some of the relatively industrialized cities in the region. The companies in the list include agriculture, furniture, steel derivatives, machines and food derivative producing enterprises. Figure 11 presents the total number of companies and the respective percentage in total. In 2002, the region had $10.8 \%$ share with 54 companies. The region had a volatile trend in 2002-2009; however, the number of companies reached 66 in 2009 and its share increased by 13.2\%. In 2015, the region had $12.6 \%$ share with 63 companies. In general, the region had an increasing trend in 2002-2015. 


\section{Central Anatolia Region}

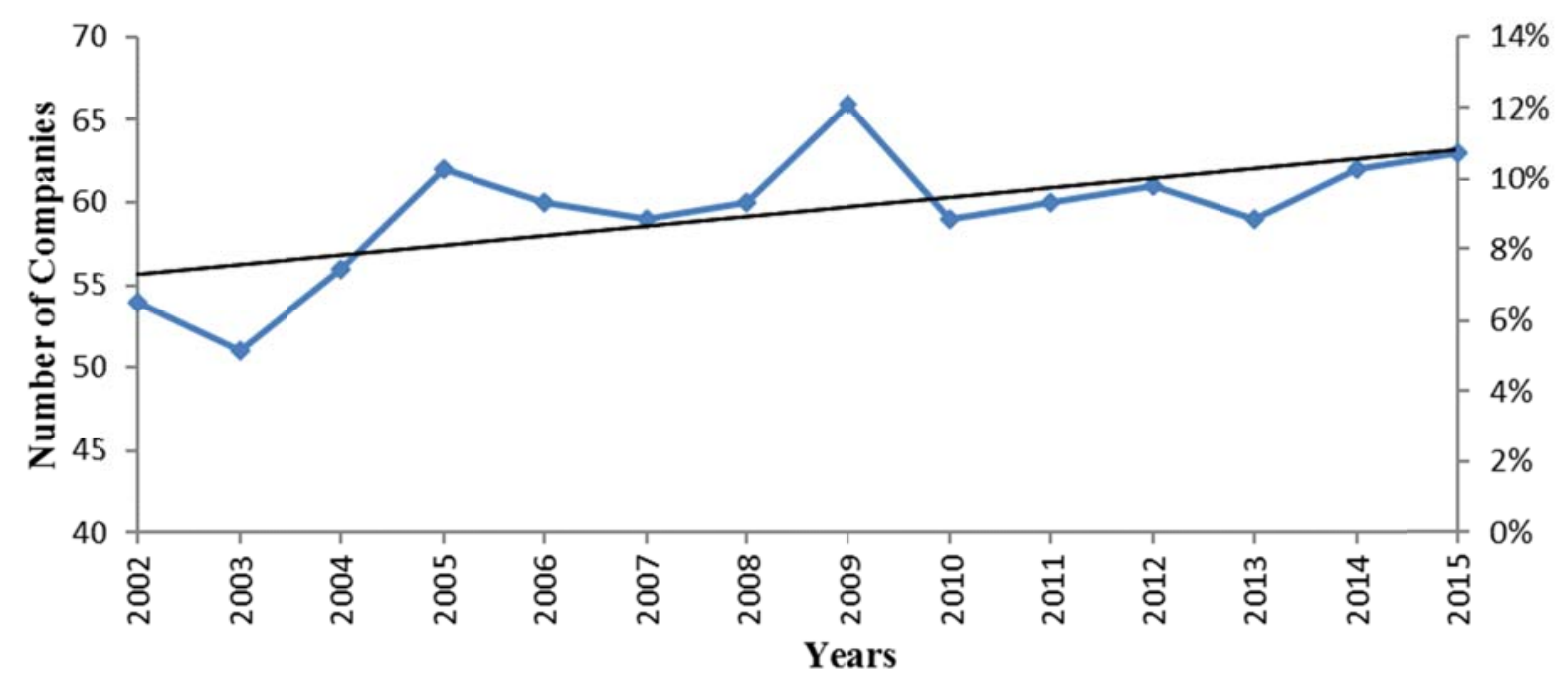

Figure 11. The number of companies in the Central Anatolia Region in 2012-2015

The Eastern Anatolia Region is in the East of Turkey and has the largest land area. The region borders with Georgia, Iran and Armenia. Despite the vastness of land, geographic obstacles and terrorism negatively affect the region's development potential. Agricultural products and mining are two important industrial activities in the region. Figure 12 presents the total number of companies and respective percentage in total. The region had a stable trend in 2002-2010 and the number of companies rose from 1 to 3 in 2010 and its share increased by $0.6 \%$. In 2015 , the region had $0.4 \%$ share with 2 companies. In general, the region had an increasing trend in 2002-2015.

\section{Eastern Anatolia Region}

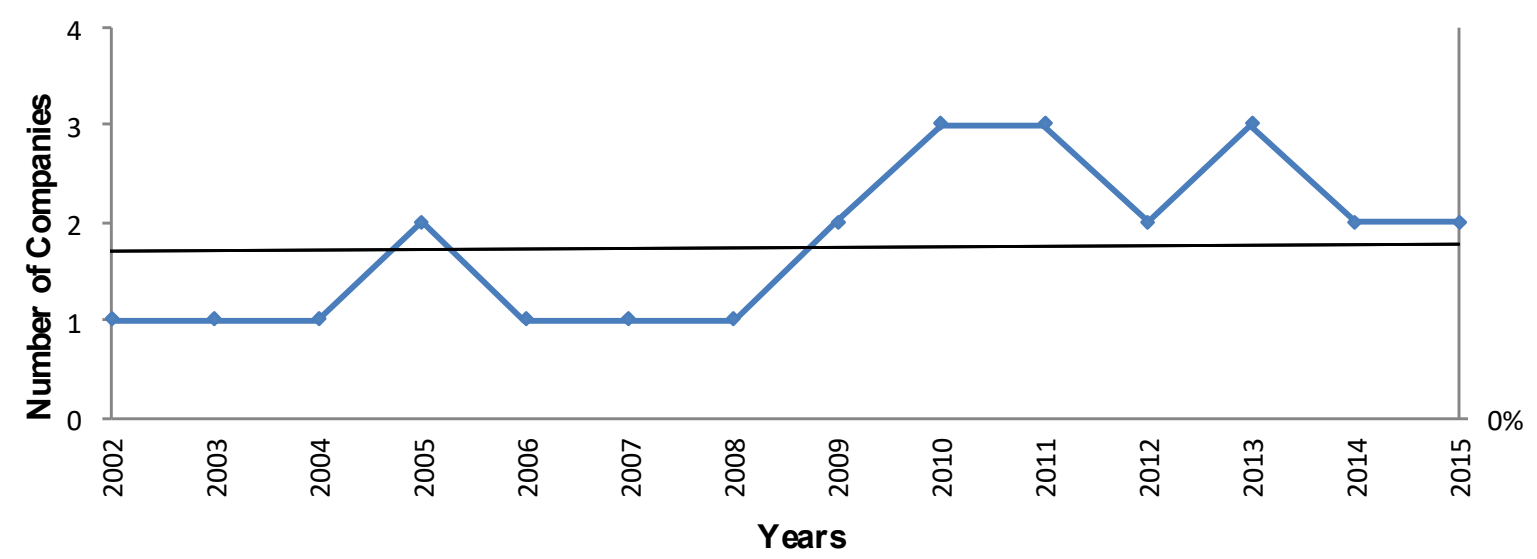

Figure 12. The number of companies in the Eastern Anatolia Region in 2012-2015

The Southeastern Anatolia region is in southeast side of Turkey with a similar structure to the Eastern Anatolia region. The region has borders with Iraq and Syria. Textile and cement are two important industrial sectors in the region. Gaziantep, a well-developed industry base, located in this region. Terror and ongoing conflict with some of the Kurdish opposition have always been a problem for investment. Figure 13 presents the total number of companies and the respective percentage in total. The analysis shows that, in 2002, the region had $2 \%$ share 
with 10 companies in the list. The region had a volatile trend in 2002-2008 but the number of companies went up to 12 in 2008 and its share increased by $2.2 \%$. In 2008-2015, the region had an increasing trend reaching a 5.2\% share with 26 companies. In general, the region had an increasing trend in terms of number of companies in 2002-2015.

\section{Southeastern Anatolia Region}

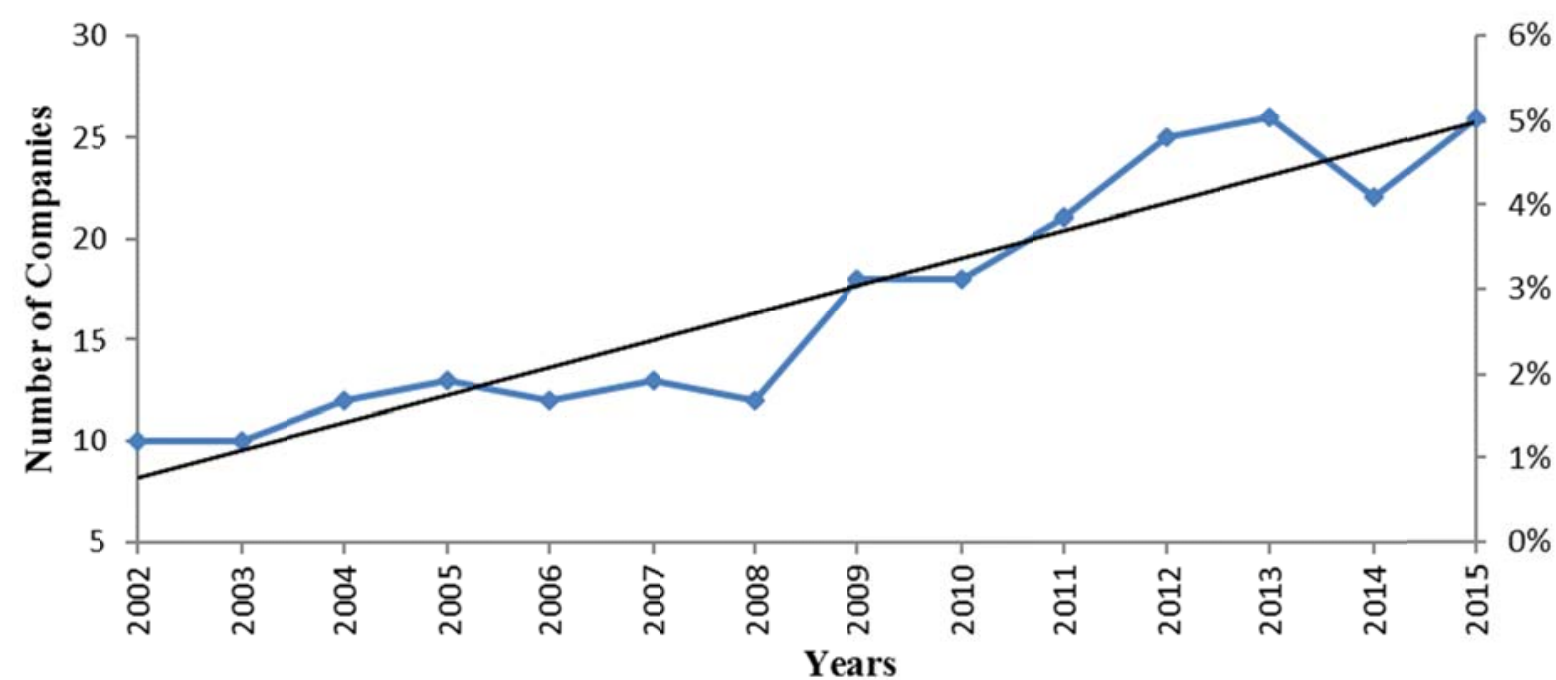

Figure 13. The number of companies in the Eastern Anatolia Region in 2012-2015

\subsection{Urban analysis}

It is also important to analyze the distribution of the largest companies in the cities. Below, eight representative cities are selected according to their size, number of companies they have and their potential, in order to track the change in the number of the largest companies throughout the years. Figure 14 presents the locations of the selected cities and Table 2 shows the change in the ratio of the city population to the total population.

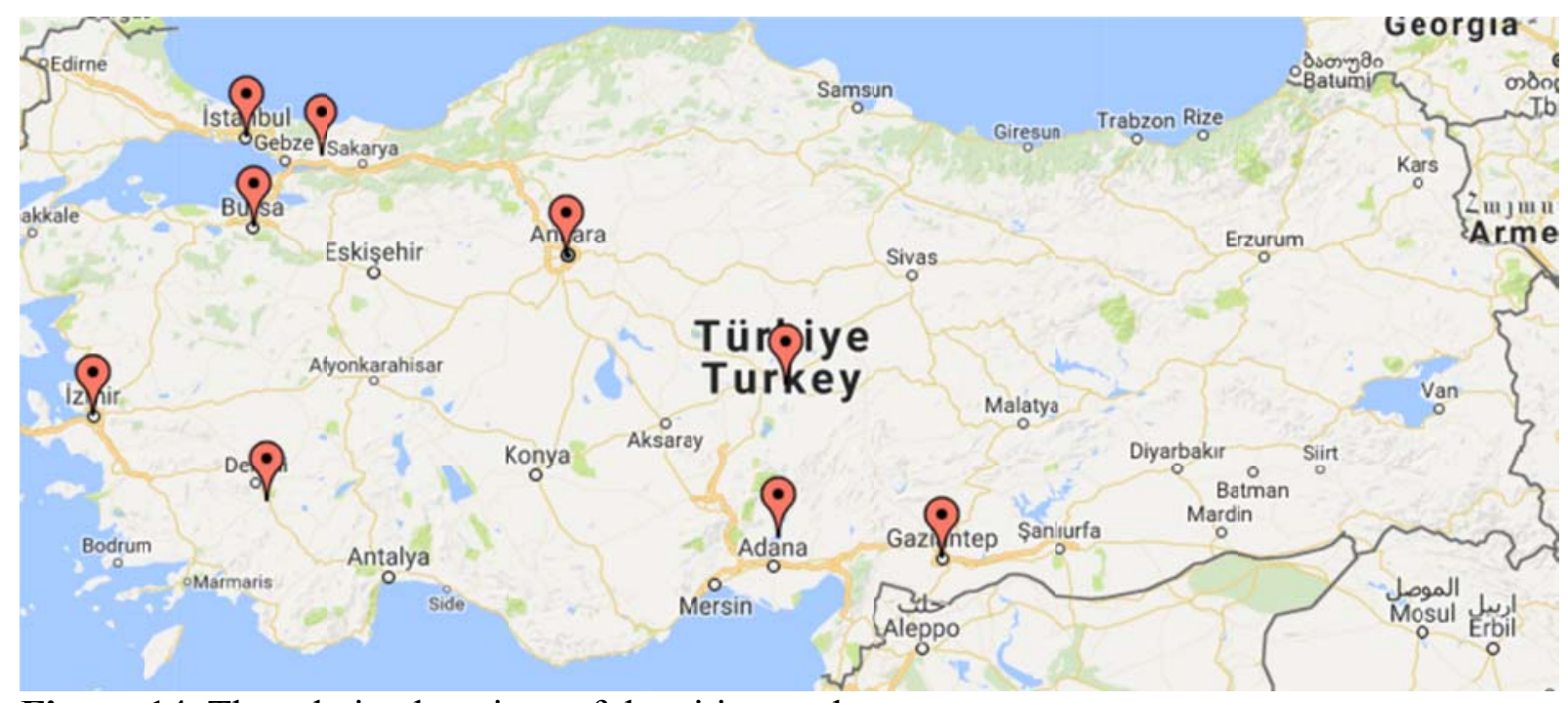

Figure 14. The relative locations of the cities on the map 
The selected cities of Istanbul, Bursa, Izmir, Ankara, Gaziantep, Denizli, Kayseri, Kocaeli and Adana are the largest in terms of population and number of companies they have. These cities are considered as the center of their regions.

Table 2. The population change of the selected cities and total population

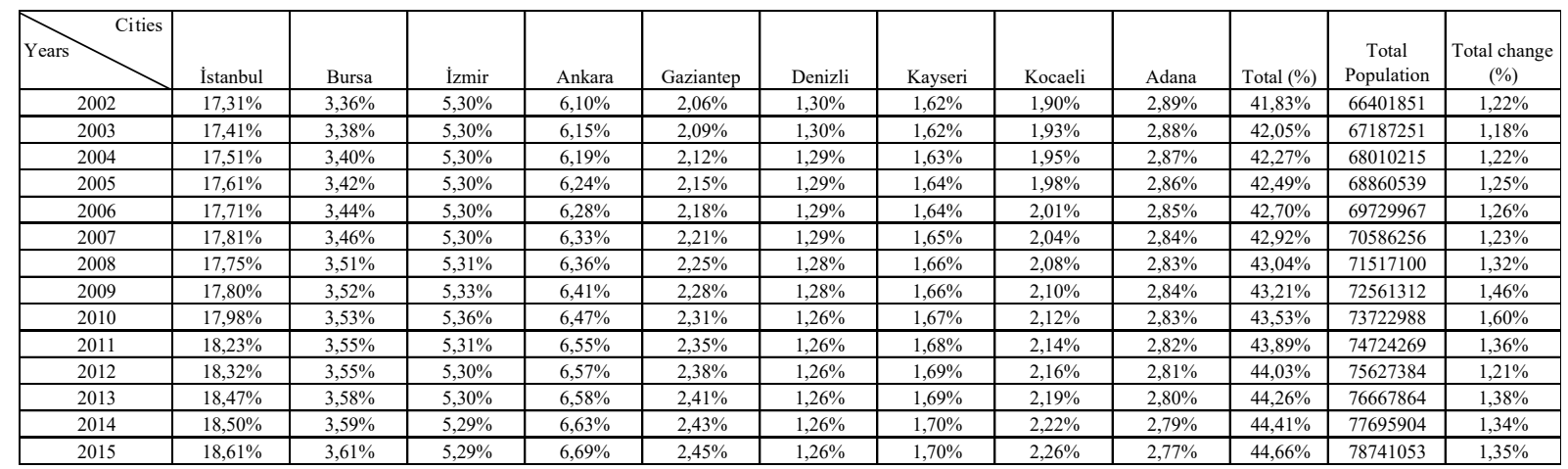

Istanbul, a city in the Marmara region of Turkey with about 15 million population, is considered as the business, culture and education center of the country. It is the most crowded and important city of the country in terms of economic and cultural aspects. The city is located on Asia and Europe and is considered as a place where continents meet. Istanbul is also the center of marine transportation, airways and ground transportation. Many national and international companies prefer Istanbul as their headquarters and the industrial infrastructure is more developed compared to other cities. Figure 15 presents the total number of companies located in Istanbul and the respective percentage in total. In 2002, the city had $45 \%$ share with 225 companies out of 500 in the list. Istanbul had a volatile trend in 20022015 and the number of companies decreased to 181 in 2015 and its share decreased by $36.20 \%$. In general, the city had an obvious decreasing trend in terms of the number of companies in 2002-2015. It is important that other cities taking some companies from Istanbul can be considered as a sign of more evenly distribution of the largest companies.

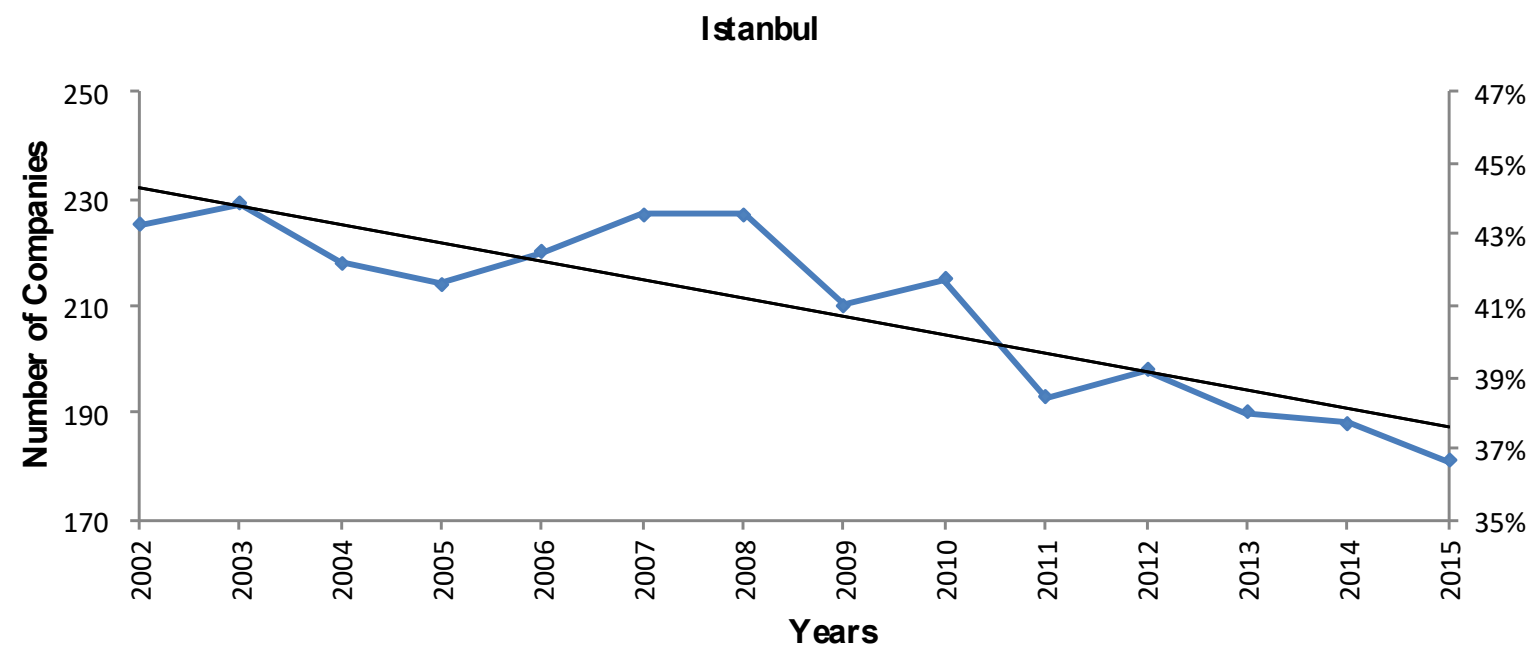

Figure 15. The number of companies in İstanbul in 2002-2015 
Bursa is another city in the Marmara region with a close proximity to Istanbul. It is the fourth crowded city of the country. Figure 16 presents the total number of companies located in Bursa and the respective percentage in total. In 2002, Bursa had a $6.6 \%$ share with 33 companies in the list. The city had a decreasing trend in 2002-2005 and the number of companies decreased to 23 in 2005 while its share went down by $4.6 \%$. Bursa had shown a volatile trend between 2005 and 2015 and the number of companies reached to 22, a share of $4.4 \%$. In general, Bursa had a decreasing trend in terms of number of companies in 20022015 .

\section{Bursa}

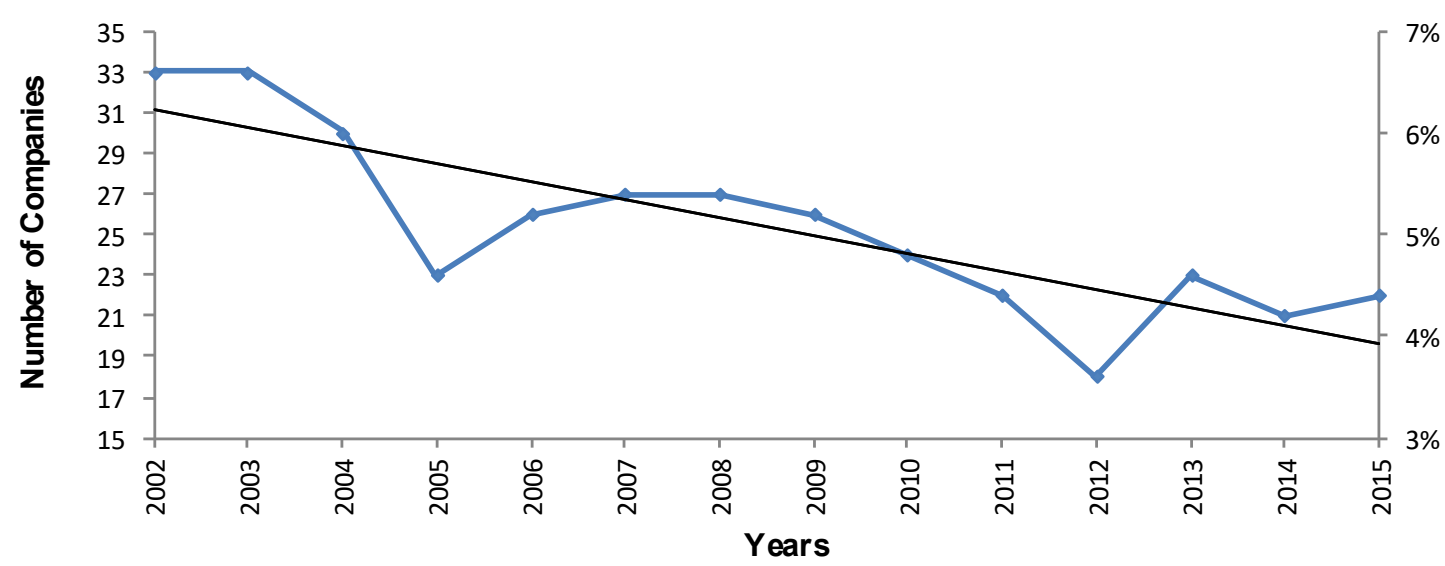

Figure 16. The number of companies in Bursa in 2002-2015

Izmir is the most important city of the Aegean region of Turkey. The city is the third most populous city in Turkey with an international exhibition center. Figure 17 presents the total number of companies located in Izmir and the respective percentage in total. In 2002, Izmir had $9.2 \%$ share with 46 companies in the list. The city had a decreasing trend in 2002-2010 and the number of companies went down to 30 in 2010 while its share decreased by $6 \%$. The number of companies rose again and reached to 38 in 2015.

\section{İzmir}

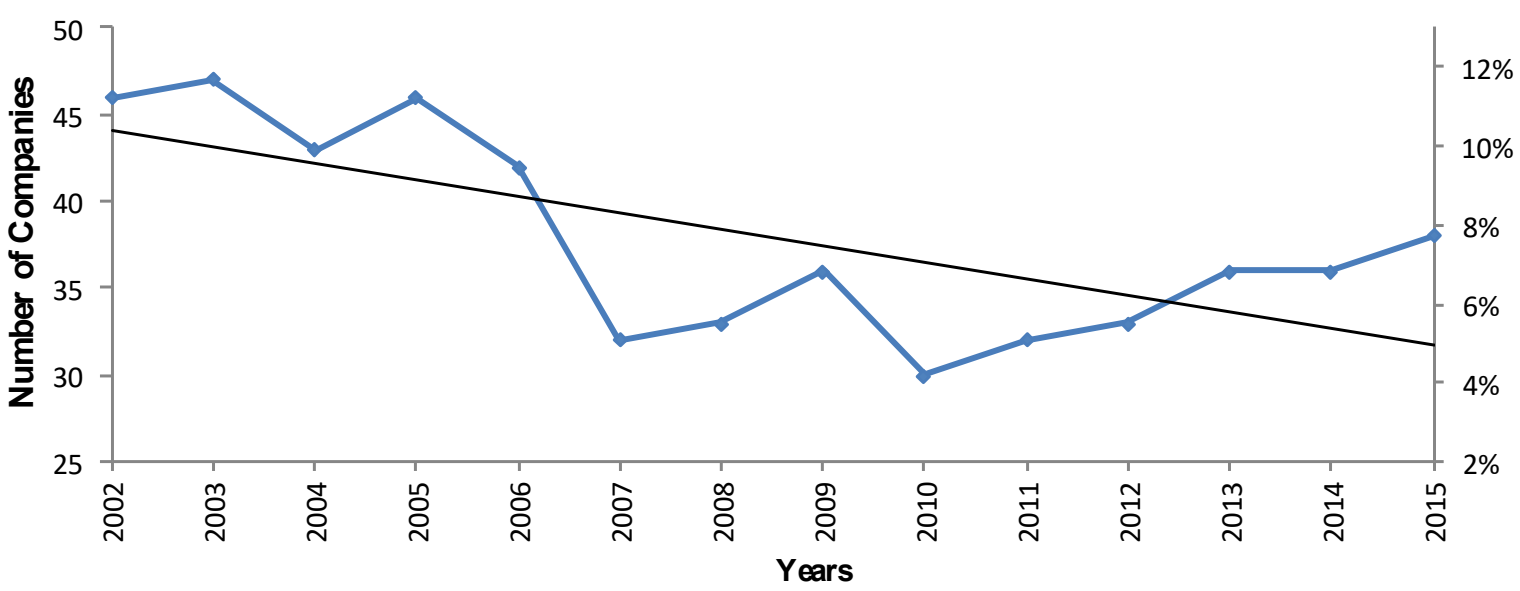

Figure 17. The number of companies in Izmir in 2002-2015 
Ankara is the capital city of the country and is located in the Central Anatolia region of Turkey. The city is at the heart of the highways and has a suitable location for truck based logistics. Figure 18 presents the total number of companies located in Ankara and the respective percentage in total. In 2002, Ankara had 24 companies with $4.8 \%$ share. The city had a volatile trend in 2002-2005 and the number of companies reached to 29 in 2005 . In 2015 the city had a 5.4\% share with 27 companies. Despite ups and downs, the city had an increasing trend.

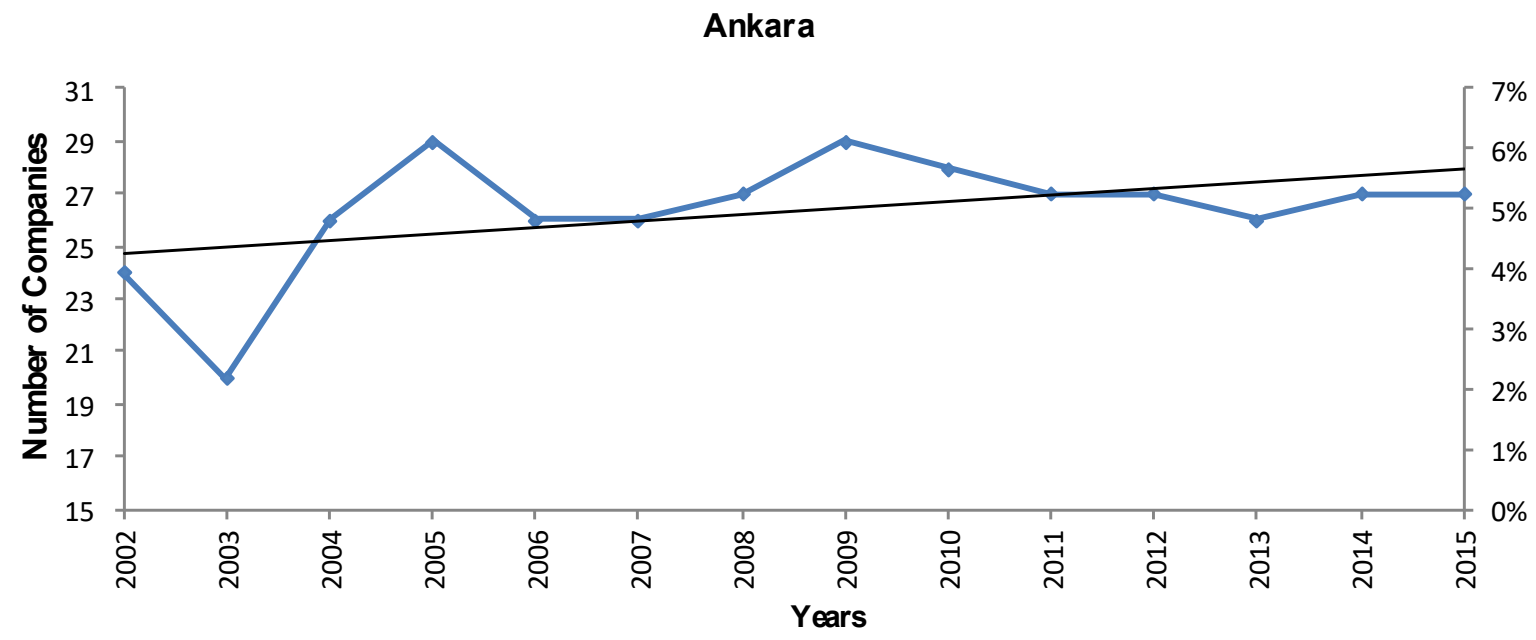

Figure 18. The number of companies in Ankara in 2002-2015

Gaziantep is located in the Southeastern region of Turkey. It is the sixth most crowded city of the country. The city is located near the Syrian border and has been benefiting the bilateral border trade. Figure 19 presents the total number of companies located in Gaziantep and the respective percentage in total. In 2002, Gaziantep had 1.8\% share with 9 companies in the list. The city had a relatively stable trend in 2002-2008 and the number of companies reached to 10 in 2008 and its share increased by $2 \%$. The number of companies increased again and in 2015 the city had a $4.8 \%$ share with 24 companies. It is obvious that the city has an increasing trend and has shown a sharp rise in recent years.

\section{Gaziantep}

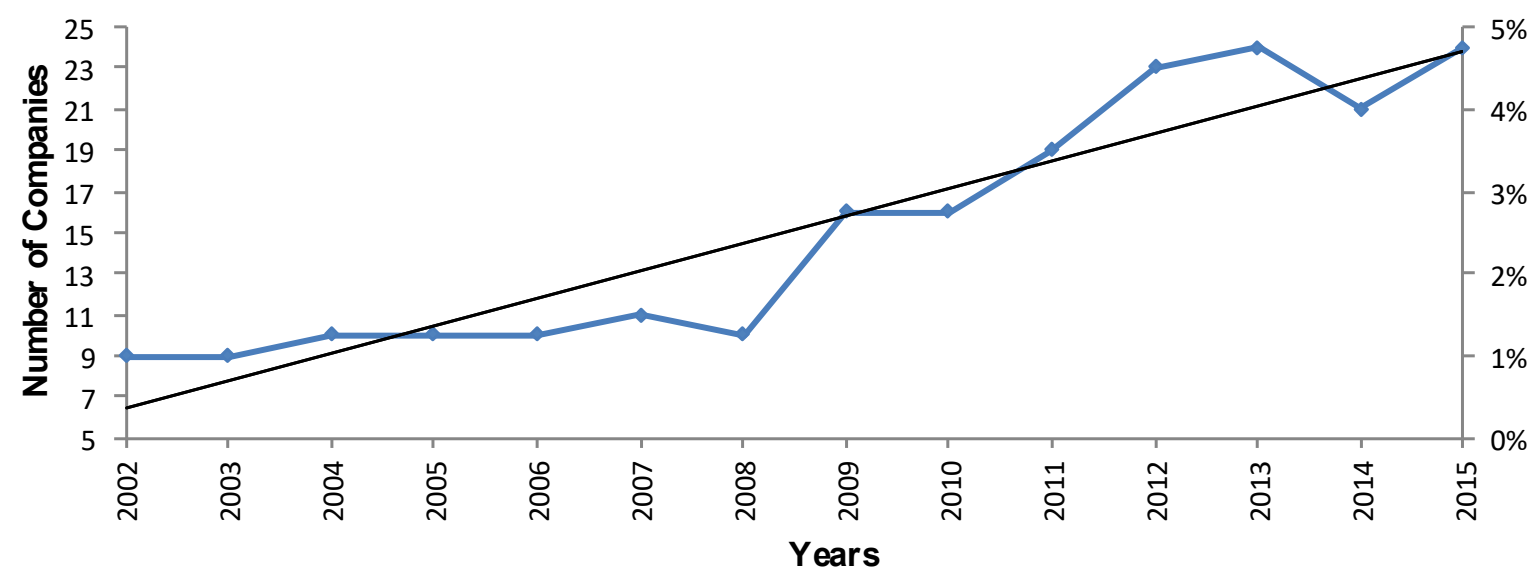

Figure 19. The number of companies in Gaziantep in 2002-2015 
Denizli is an important city of the Aegean region of the country. Figure 20 presents the total number of companies located in Denizli and the respective percentage in total. In 2002, Denizli had a $2.6 \%$ share with 13 companies in the list. The city had a volatile trend in 20022015 and the number of companies was 11 in 2015 with a share of $2.2 \%$. The city is well known for textile industry and is home for many small and midsized companies. The region is also known for its dried fruits products. Denizli has lost its importance in terms of the number of largest companies it has over the years.

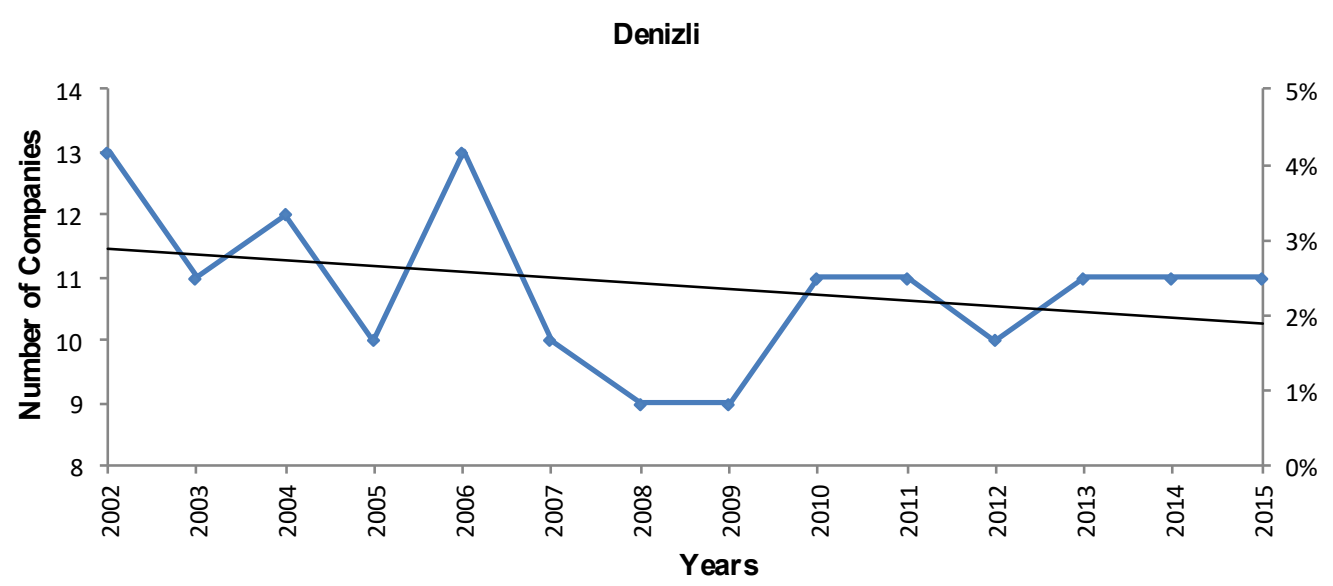

Figure 20. The number of companies in Denizli in 2002-2015

Kayseri is a city of the Central Anatolia region of Turkey. It is the second most populous city of the region with extended manufacturing facilities and developed industrial parks. The city is considered as the center for furniture industry and is home for many suppliers. Figure 21 presents the total number of companies located in Kayseri throughout the years. In 20022004, Kayseri had a $2.8 \%$ share with 14 companies in the list. The city had a volatile trend in 2002-2010 and the number of companies decreased to 10 and its share decreased by $2 \%$. The number of companies increased again and reached 14 in 2015. In general, the region has a decreasing trend in terms of number of companies in 2002-2015.

Kayseri

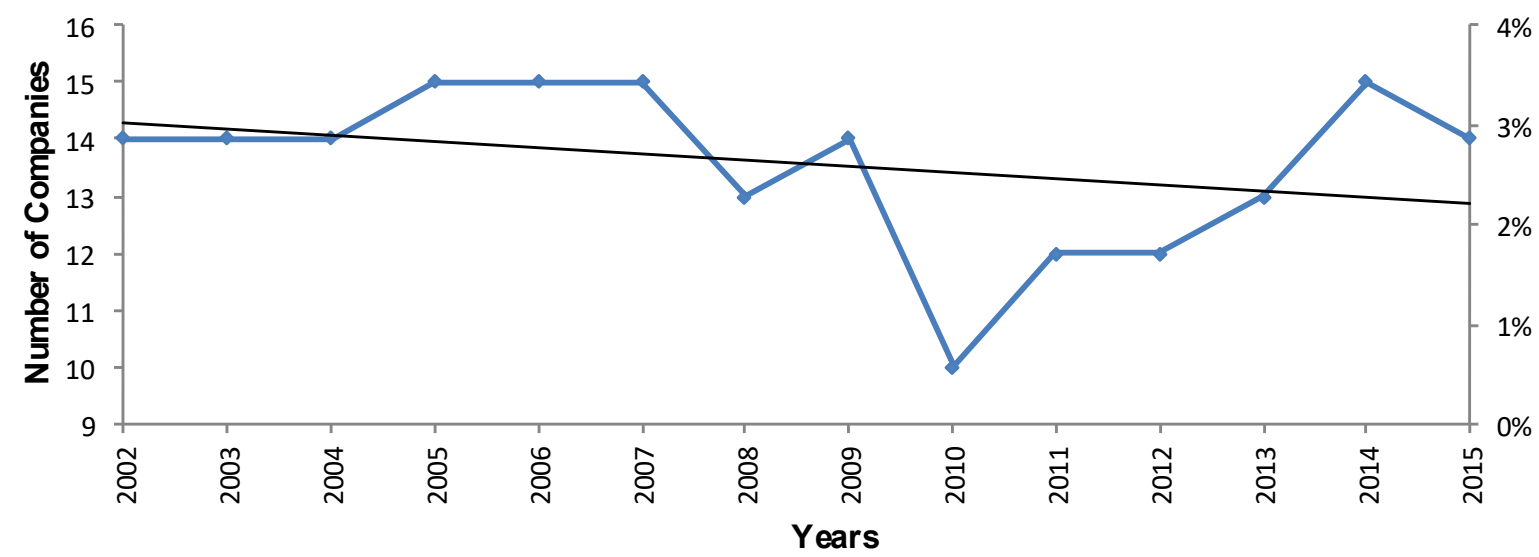

Figure 21. The number of companies in Kayseri in 2002-2015 
Kocaeli is another important city of the Marmara region with close proximity to Istanbul. The city is considered as a center for industrial plants and manufacturing facilities. The manufacturing facilities for automotive industry and spare parts are located within the city. The advanced transportation opportunities and the availability of high skilled workforce are other factors attracting investments to Kocaeli. Figure 22 presents total number of companies located in Kocaeli and respective percentage in total. In 2002, the city had 12 companies in the list with a share of $2.2 \%$. The city has shown a tremendous increase until 2015 and reached to 32 companies and its share increased by $6.4 \%$. In general, the region had an increasing trend in terms of the number of companies in 2002-2015.

\section{Kocaeli}

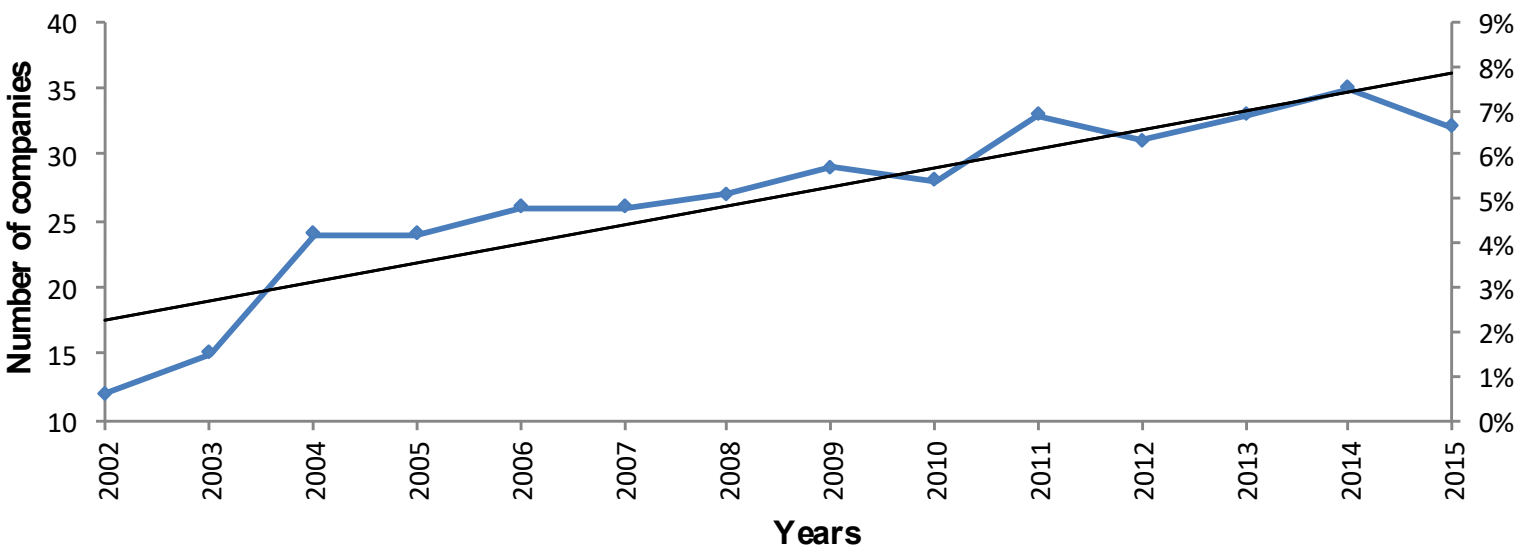

Figure 22. The number of companies in Kocaeli in 2002-2015

Adana is the most industrialized city in the Mediterranean region with considerable agricultural lands. Figure 23 presents the total number of companies located in Adana and the respective percentage in total. The city had 12 companies in the list in 2002 and the numbers decreased until 2006 reaching 6 companies. The number of companies increased again and reached 15 in 2015. The city had an increasing trend in terms of number of companies in 2002-2015.

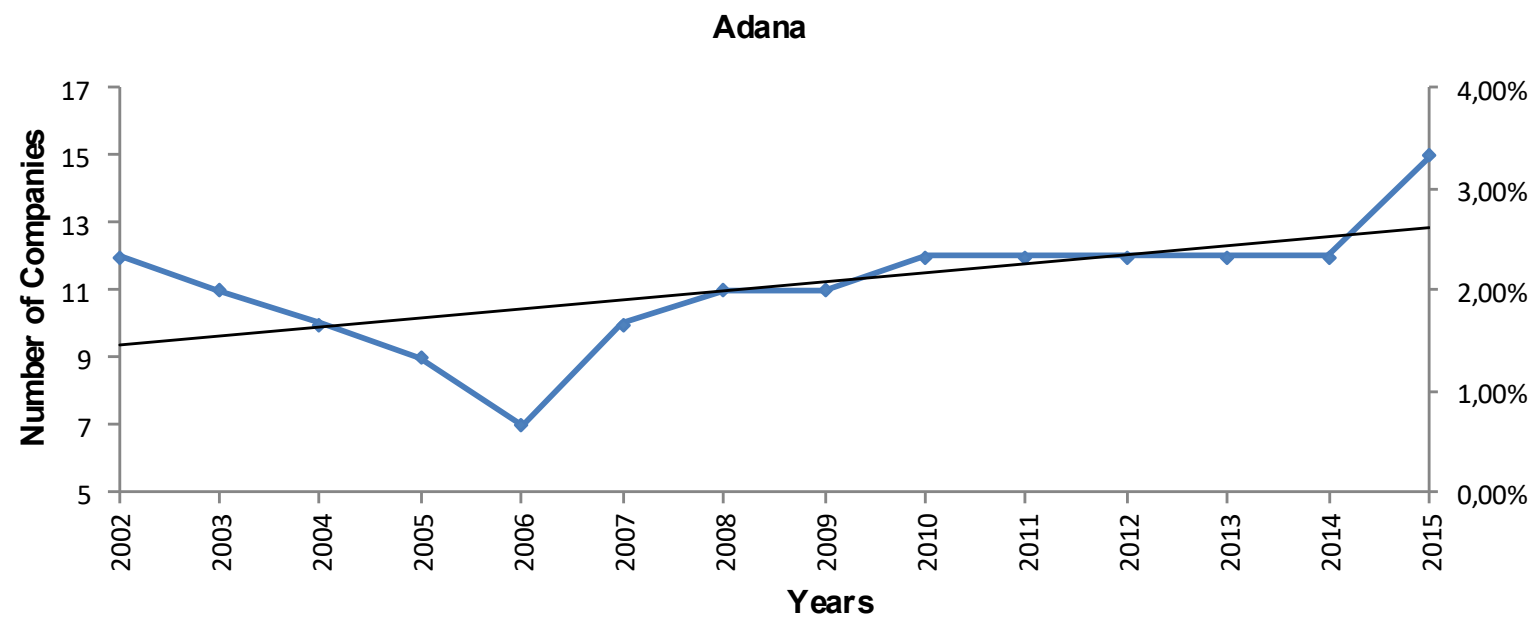

Figure 23. The number of companies in Adana in 2002-2015 


\section{Discussion}

The regional analysis shows that the Marmara region which is considered as the main center for manufacturing, tourism and finance loses its importance in terms of the number of the largest companies in the region. The region had 303 companies in 2012 and completed 2015 with 264 companies. A similar pattern is observed for the Aegean region and the number of companies has shown a significant variability between 2002 and 2015. It is obvious that the companies in the Mediterranean, Southeastern Anatolian, Central Anatolian, Eastern Anatolian and Black Sea regions are growing and finding a place in the list. Table 3 presents the statistical significance of the trend analysis. The results show that the Mediterranean and Southeastern Anatolian regions are the fastest growing regions in terms of the number of the largest companies they have. The Marmara region which is still the dominant region is losing its largest companies to other regions. The Central Anatolian and Black Sea regions are also growing while the trend value for the Black Sea region is not statistically significant.

Table 3. The statistical results for regional analysis

\begin{tabular}{|c|c|c|}
\hline Region & Trend value & $\mathrm{p}$-value \\
\hline Mediterranean Region & 1.35 & $<0.05$ \\
\hline Eastern Anatolia Region & 0.13 & $<0.05$ \\
\hline Aegean Region & -0.63 & $<0.05$ \\
\hline Southeastern Anatolia Region & 1.35 & $<0.05$ \\
\hline Central Anatolia Region & 0.58 & $<0.05$ \\
\hline Black Sea Region & 0.39 & 0.10 \\
\hline Marmara Region & -2.36 & $<0.05$ \\
\hline
\end{tabular}

The analysis for the cities show that Kocaeli and Gaziantep are the fastest growing cities in terms of the number of the largest companies they have. Table 4 presents the statistical significance of the trend analysis. Adana and Ankara are other growing cities according to the analysis. Istanbul, historically the most important city of the country, had a bad performance within the analysis period. The city loses some of its largest companies to other cities. Izmir, Bursa, Kayseri and Denizli lost their significance relatively within the analyzed period of time. Given that the listed cities are the most important ones, it can be claimed that industrial change seriously affects business activities and the companies in other cities grow and find a place on the list.

The results of the statistical analysis are not significant for Ankara, Denizli and Kayseri. The Marmara region has been losing the largest companies and, this change can be observed in Istanbul and Bursa. Kocaeli on the other hand is an exception to this fact and unlike its region the number of companies in the city has been increasing. The Aegean region loses the largest companies and İzmir and Denizli had negative trends. The results for the cities confirm that of the regional analysis. 
Table 4. The statistical results for regional analysis

\begin{tabular}{|c|c|c|c|}
\hline City & Region & Slope & $\mathrm{p}$-value \\
\hline Istanbul & Marmara & $-3,46$ & $<0,05$ \\
\hline Bursa & Marmara & $-0,89$ & $<0,05$ \\
\hline Izmir & Aegean & $-0,95$ & $<0,05$ \\
\hline Ankara & Central Anatolia & 0,25 & 0,09 \\
\hline Gaziantep & Southern Anatolia & 1,34 & $<0,05$ \\
\hline Denizli & Aegean & $-0,09$ & 0,27 \\
\hline Kayseri & Central Anatolia & $-0,11$ & 0,29 \\
\hline Kocaeli & Marmara & 1,43 & $<0,05$ \\
\hline Adana & Mediterranean & 0,26 & $<0,05$ \\
\hline
\end{tabular}

\section{Conclusion}

The industrial production plants and facilities bring employment, suppliers and new investment which is important for a region or a city. Industrial facilities in Turkey have not been evenly distributed as a consequence of problems such as transportation opportunities, terrorism, population, and land area. In this paper, we have analyzed the list of the largest 500 companies in Turkey to track the regional development and change. We have first analyzed the number of companies in the Aegean, Black Sea, Central Anatolia, Eastern Anatolia, Marmara, Mediterranean, and South Eastern Anatolia in 2012-2015. We have used an algorithm to track the performance of the companies over the years and we have used trend analysis to show their long term direction. Then the results are combined for each region in an effort to show the regional distribution. Each region has its own characteristics and regionbased industrial plants. It is shown that the Marmara region which has been the dominant region loses its largest companies to other regions. The Aegean region is another region with a decreasing number of large companies. On the other hand, the Mediterranean and Southeastern Anatolian regions are the fastest growing regions in terms of the number of the largest companies. The regions of the Black Sea, Central Anatolia and Eastern Anatolia has enjoyed an increase in the number of the largest companies.

We have also analyzed the most important cities including Istanbul, Bursa, Izmir, Ankara, Gaziantep, Denizli, Kayseri, Kocaeli and Adana. We have followed a similar analysis pattern as we do in regional analysis to find the long term direction. It is obvious that Istanbul, the most crowded and important city, loses its power rapidly while Bursa, İzmir, Denizli and Kayseri other cities to lose the largest companies. Kocaeli and Gaziantep are the rising cities along with Ankara and Adana. The results show that other cities in Turkey started to have the largest companies, lost by cities such as Istanbul, within their borders which is a sign of a more evenly distributed development.

\section{References}

[1] Keskek, S., Orhan, M. 2010. Inflation and Inflation Uncertainty in Turkey. Applied Economics. 42:1281-1291.

[2] Turkstat, 2017, Turkish Statistical Institution, http://www.turkstat.gov.tr/ 
[3] Sacik, S. Y. 2009. Dis Ticaret Politikasi ve Ekonomik Buyume Iliskisi: Teorik Acidan Bir Inceleme. KMU IIBF Dergisi. 16:162-171.

[4] Egeli, H. A. 2001. Dis Ticaret Acisindan Sanayilesme Stratejileri ve Turkiye Acisindan Degerlendirmesi. Sosyal Bilimler Dergisi. 2:149-161.

[5] Bilgin, C., Sahbaz, A. 2009. Turkiye'de Buyume ve Ihracat Arasindaki Nedensellik 1liskileri. Gaziantep Universitesi Sosyal Bilimler Dergisi. 8(1):177-198

[6] Florida, R.L., Kenney, M. 1988. Venture Capital, High Technology and Regional Development. Regional Studies 22(1): 33-48.

[7] Jednak, S., Kragulj, D., Bulajic, M. 2017. A comparative analysis of development in Southeast European countries. Technological and Economic Development of Economy : $1-18$.

[8] Armstrong, H. W., Read, R. 2002. The phantom of liberty: economic growth and the vulnerability of small states. Journal of International Development 14: 435-458.

[9] Moore, B., Tyler, P., Elliott, D. 1991. The Influence of Regional Development Incentives and Infrastructure on the Location of Small and Medium Sized Companies in Europe. Urban Studies 28(6):1001-1026.

[10] Türkcan, B., Çalışkan, E. T., \& Kaya, A. A. (2009). Industrial clusters as a regional development tool: a spatial analysis on Turkey. EconAnadolu 2009: Anadolu International Conference in Economics June 17-19, 2009, Eskişehir, Turkey, pp.1-29.

[11] Onis, Z., \& Senses, F. (Eds.). (2009). Turkey and the global economy: Neo-liberal restructuring and integration in the post-crisis era. Routledge.

[12] Senses, Fikret. "Understanding the Process of Economic Change in Turkey: An Institutional Approach.", Nova Science Pub., (2011): 197-199.

[13] Erserim, A. (2012). The impacts of organizational culture, firm's characteristics and external environment of firms on management accounting practices: an empirical research on industrial firms in Turkey. Procedia-Social and Behavioral Sciences, 62:372-376.

[14] Rezende, J. F. D. C., Sinay, M. C. F. D. 2016. Methodology for leading indicators on sustainable regional development. Revista de Administração Pública. 50(3):395-423.

[15] Horsley, J., Prout, S., Tonts, M., Ali, S.H. 2015. Sustainable livelihoods and indicators for regional development in mining economies, The Extractive Industries and Society, 2(2):368-380.

[16] Harrington, J.W., Burns, K., Cheung, M., 1986. Market-Oriented Foreign Investment and Regional Development: Canadian Companies in Western New York. Economic Geography, 62(2):155-166.

[17] Lipshitz, G. 1993. The main approaches to measuring regional development and welfare. Social indicators research 29(2):163-181.

[18] Wu, X., Strange, R. (2000). The location of foreign insurance companies in China. International Business Review. 9(3) : 383-398.

[19] Karreman, B., Burger, M. J., van Oort, F. G. 2017. Location Choices of Chinese Multinationals in Europe: The Role of Overseas Communities. Economic Geography. 93(2): 131-161. 
[20] Basile, R., Castellani, D., and Zanfei, A. 2008. Location choices of multinational firms in Europe: The role of EU cohesion policy. Journal of International Economics 74 (2): 328-40.

[21] De Beule, F., and Duanmu, J.-L. 2012. Locational determinants of internationalization: A firmlevel analysis of Chinese and Indian acquisitions. European Management Journal 30 (3): 264-77.

[22] Goerzen, A., Asmussen, C. G., and Nielsen, B. B. 2013. Global cities and multinational enterprise location strategy. Journal of International Business Studies 44 (5): 427-50.

[23] Head, K., and Mayer, T. 2004. Market potential and the location of Japanese investment in the European Union. Review of Economics and Statistics 86 (4): 959-72.

[24] Kelley, D., Coner, J. K., and Lyles, M. A. 2013. Chinese foreign direct investment in the United States: Location choice determinants and strategic implications for the state of Indiana. Business Horizons 56 (4): 443-51.

[25] Kaygalak, I., \& Reid, N. (2016). The geographical evolution of manufacturing and industrial policies in Turkey. Applied Geography 70: 37-48.

[26] Akgüngör, S. (2006). Geographic concentrations in Turkey's manufacturing industry: identifying regional highpoint clusters. European Planning Studies 14(2): 169-197.

[27] Akgüngör, S., Kumral, N., \& Lenger, A. (2003). National industry clusters and regional specializations in Turkey. European Planning Studies 11(6): 647-669.

[28] Sevgi, C. (1994). Sanayileşme Sürecinde Türkiye ve Sanayi Kuruluşlarının Alansal Dağglımı (The process of industrialization in Turkey and spatial distribution of industrial organizations-in Turkish). Istanbul: Beta basım.

[29] Storper, M. (2011). Why do regions develop and change? The challenge for geography and economics. Journal of Economic Geography 11: 333-346.

[30] Elvan, L., Sorguç, N., Kazancık, L. B., \& Öztürk, A. (2005). Türkiye'de Bölgesel Gelişme Politikaları: Sektör-Bölge Yığınlaşmaları. TÜSİAD, İstanbul.

[31] Kirk, K., Tableporter, J., Senn, A., Day, J., Cao, J., Fan, Y., McGinnis, L. 2010. Framework for Measuring Sustainable Regional Development for the Twin Cities Region.

http://www.cura.umn.edu/sites/cura.advantagelabs.com/files/publications/L2010-2.pdf

[32] Meyer, D.F., Jongh, J.D., Meyer, N. 2016. The formulation of a composite regional development index. International Journal of Business and Management Studies 8(1): 100-116

[33] Antonelli, C. 1995. The Economics of Localized Technological Change and Industrial Dynamics. 3. Springer Netherlands.

[34] Berument, M.H., Dincer, N.N., Mustafaoglu, Z. 2014. External income shocks and Turkish exports: A sectoral analysis. Economic Modelling 37:.476-484.

[35] UN, International Standard Industrial Classification of All Economic Activities, Statistical papers Series M No. 4/Rev.4, UN Department of Economic and Social Affairs, 2008, Available online at: https://unstats.un.org/unsd/publication/seriesM/ seriesm 4 rev4e.pdf 